WHOI-89-49

IMET TR-89-05

\title{
Improved Meteorological Measurements from Buoys and Ships (IMET): Preliminary Report on Barometric Pressure Sensors.
}

by

Richard E. Payne, Gennaro H. Crescenti and Robert A. Weller

Woods Hole Oceanographic Institution

Woods Hole, Massachusetts 02543

December 1989

\section{Technical Report}

Funding was provided by the National Science Foundation under Grant No. OCE-87-09614

Reproduction in whole or in part is permitted for any purpose of the United States Government. This report should be cited as:

Woods Hole Oceanog. Inst. Tech. Rept., WHOI-89-49, IMET TR-89-05.

Approved for publication; distribution unlimited.

Approved for Distribution:

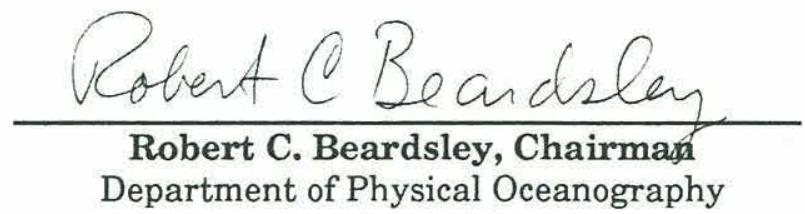




\section{Abstract}

Stability tests over periods ranging from 3 to 19 months have been carried out on Paroscientific models 215-AT and 760-15A, AIR DB-1A, Rosemount 1201F1B, Setra 270 and Heise 623 electronic barometers. The Paroscientific barometers had the highest accuracy, stability, and price, and the lowest power consumption. The Rosemount 1201F1B had excellent stability but high power consumption as well as price. The AIR DB-1A and Setra 270 have good stability and moderate power consumption and price. The tests are being expanded to include inexpensive sensors. 


\section{Table of Contents}

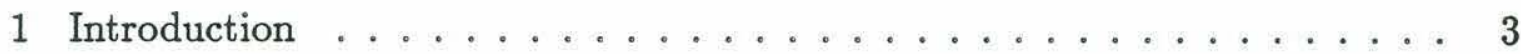

2 Description of Sensors . . . . . . . . . . . . . . 3

2.1 Paroscientific Model 215-AT . . . . . . . . . . . . . 4

$2.2 \quad$ Paroscientific $760-15 \mathrm{~A} \ldots \ldots \ldots \ldots \ldots \ldots$

$2.3 \quad$ AIR DB-1A . . . . . . . . . . . . . . . 4

2.4 Rosemount Model 1201F1B . . . . . . . . . . . . . 5 5

2.5 Setra Systems Model 270 . . . . . . . . . . . . . . . 5

$2.6 \quad$ Heise Model 623 (Dresser Industries) . . . . . . . . . . . . 5

3 Data Analysis . . . . . . . . . . . . . . . . . . 6

3.1 February 1988 to Present . . . . . . . . . . . . 6

3.21 April 1989 to Present . . . . . . . . . . . . . . 9

4 Summary and Conclusions . . . . . . . . . . . . . . . 11

Acknowledgements . . . . . . . . . . . . . . . . . . . . 12

Tables . . . . . . . . . . . . . . . . . . . . . . . 13

Appendix A - Manufacturer Addresses . . . . . . . . . . . . . 15 


\section{Introduction}

Several components of the U.S. effort in the World Ocean Circulation Experiment (WOCE) will require observations of air-sea heat and momentum fluxes from both ships and buoys. A group at the Woods Hole Oceanographic Institution (WHOI) is developing and testing instrumentation to provide Improved Meteorological measurements (IMET) which will meet the requirements of these WOCE components. Here we report on the performance of barometric pressure sensors.

Reliable surface barometric pressure data are needed over the oceans in order to understand the nature and movement of synoptic and mesoscale weather systems. Pressure transducers are sought for use on moored buoys and ships that exhibit long term stability and accuracy while less expensive pressure transducers are needed for expendable drifting buoys. We require a long term system accuracy of $1 \mathrm{mb}$ or better and low power consumption.

Daily readings of ambient barometric pressure have been made for nearly two years with a group of ten Atmospheric Instrumentation Research, Inc. (AIR) digital barometers. Three months ago we added several of the other available good quality electronic barometers to our study. Here we report on the comparisons between the various barometers for both sets. Currently we are in the process of automating the data taking and adding several other sensors, including some that are quite inexpensive.

\section{Description of Sensors}

There are two basic principles used by the manufacturers of good electronic barometers: Paroscientific uses a quartz crystal resonator whose frequency of oscillation varies with pressure induced stress; the rest all sense the deflection of a 
diaphragm, by an optical lever in the case of the Heise and capacitatively for the remainder.

A total of ten AIR sensors was used in the study and two each of the others. Table 1 lists the manufacturer's specifications for all six types of sensors and the Appendix gives addresses and telephone numbers of all the manufacturers.

\subsection{Paroscientific Model 215-AT}

The basic Paroscientific barometric pressure sensor, this provides frequency outputs for both pressure and temperature. Because corrected pressure is a complicated function of both outputs which requires a wide range of precisely controlled temperature and pressure during the calibration, it is necessary to return the sensor to the manufacturer for recalibration.

\subsection{Paroscientific $760-15$ A}

Paroscientific terms this their "portable standard". It consists of a Model 760-15A sensor selected for stability and the necessary analog and digital circuitry to digitize the frequency signals, compute corrected barometric pressures and sensor

temperatures, and make them available at an RS-232 connector as well as on an LCD display. An extensive set of commands controls the barometer's operation and output format through the RS-232 port.

\subsection{AIR DB-1A}

This barometer also contains analog and digital circuitry. The output is available in either serial (RS-232 or TTL) or parallel mode. Communications parameters and the number of measurements over which it averages are jumper selectable. Because the calibration constants are burned into an erasable programmable read only memory (EPROM), the sensors must be returned to the 
AIR for complete recalibration. Recently AIR has made available a PC program and EPROM burner which allow the user to make routine recalibrations which involve comparing with a standard and correcting the zero offset in the EPROM.

\subsection{Rosemount Model 1201F1B}

One wall of the evacuated reference chamber is made of quartz which forms part of a capacitor whose capacitance changes as pressure changes vary the deformation of the quartz. Analog circuitry corrects for temperature effects and produces a high level DC signal linear in the barometric pressure. This could be calibrated by a user with a good pressure standard.

\subsection{Setra Systems Model 270}

The sides of an evacuated reference cavity are ceramic with gold electrodes on the inside surfaces forming a capacitor. As one of the capsule walls flexes from changing pressure, the capacitance changes. Analog circuitry corrects for temperature effects and produces a high level DC signal linear in barometric pressure. This could be calibrated by a user with a good pressure standard.

\subsection{Heise Model 623 (Dresser Industries)}

The flexing of one wall of an evacuated chamber is sensed optically with an LED and two photodiodes. Analog circuitry corrects for temperature effects and converts the diaphragm position to a high level DC voltage which is linear in barometric pressure. This could be calibrated by a user with a good pressure standard. 


\section{Data Analysis}

We will consider the data in two groups. Group one includes all the AIRs for the full period they have been monitored, February 1988 to the present and also the Paroscientific portable standard from November 1988. Note that, except for the last month of data, all sensors have had power applied to them continuously. Group two includes the other sensors described in section 2 .

\subsection{February 1988 to Present}

Daily readings of our ten AIR barometers began in early February 1988 and have continued to the present. Only two of the AIRs have uninterrupted data through the whole period, S/Ns 34 and 55. The rest have all had periods when they were unavailable either due to being deployed in an experiment or returned to AIR for repair. Figures 1-20 represent this data set.

After the first six months of monitoring we selected S/N 34 for comparison with the others. There were several which were tracking together well but of that group $\mathrm{S} / \mathrm{N} 34$ was the oldest and it had been over a year since it had been recalibrated. In January 1987 it had had a thorough upgrading of critical electronic components by AIR and was recalibrated.

There were four opportunities to check the calibration of S/N 34 against other AIR barometers which had just been recalibrated or had their calibrations verified by AIR. These checks are listed in Table 2. Two other barometers were returned by AIR after recalibration during the comparison period but these sensors behaved so anomolously we do not trust their calibrations. These results provide a check that $\mathrm{S} / \mathrm{N} 34$ was within $0.2 \mathrm{mb}$ relative to the AIR pressure standard at several specific times. Starting on day 308 we added the Paroscientific portable standard barometer to the comparison. Paroscientific claims an absolute accuracy of $0.1 \mathrm{mb}$, better than that of the AIRs. Figure 10 shows that AIR S/N 34 was within $0.3 \mathrm{mb}$ of the 
Paroscientific readings from day 300 to the present. Thus, from all available indications $\mathrm{S} / \mathrm{N} 34$ remained within $0.3 \mathrm{mb}$ of the true barometric pressure for the entire length of the comparison.

Two plots are given for each AIR barometer. One is the difference between readings of that sensor and AIR 34 from February 1988 to the present; the other is the difference between readings of that sensor and the Paroscientific portable standard (termed PARO PS on the plots) for the period we have owned it (day 308 to the present). The abscissa for both is consecutive year day starting on January 1 , 1988. Note that the plots of AIR 34 are an exception: they are both of the difference with the Paroscientific but with time axes corresponding to the two sets of time axes for the other AIRs. Notes have been added to the first of the two plots for each sensor for significant repairs or absences from the comparison.

In the next few paragraphs we will comment on the performance of the individual AIR sensors. We will make a general comment here. From the start of the comparison to day 573 , power was applied to all the sensors continuously. With the start of the pressure cycling test, power has been applied only a few minutes before the readings are taken and turned off directly afterward. Four AIRs show increased scatter after day $573, \mathrm{~S} / \mathrm{Ns} 34,58,70,115$, although only S/Ns 58 and 115 are experiencing the pressure cycling. In the cycling study a pressure of $200 \mathrm{mb}$ above ambient has been impressed on AIR S/N 58 and 115 once per second, 24 hours a day.

AIR S/N 34, Figures 1, 2: Relative to the Paroscientific 760-15A, it remained within $0.3 \mathrm{mb}$ of the correct pressure.

AIR S/N 44, Figures 3, 4: The last repair which would have affected its performance was in April 1985. It is quite stable and has remained within $0.5 \mathrm{mb}$ of the true pressure during the 380 days it has been monitored. Although the actual drift rate approximated $1 \mathrm{mb} / \mathrm{yr}$ from day 300 to 500, it then changed sign and drifted back. 
AIR S/N 54, Figures 5, 6: This was originally purchased in 1984 and has not been repaired, updated, or recalibrated since then. Although its bias of $-0.6 \mathrm{mb}$ at the beginning of the comparison was reasonable, the drift rate approximated $1 \mathrm{mb} / \mathrm{yr}$ between days 300 and 500, like S/N 44. Since AIR has made several circuit improvements since 1984, it probably should be returned for upgrading.

AIR S/N 55, Figures 7, 8: This barometer had a leaky cell replaced in 1985 and again in 1987. Now it appears quite stable and has remained within $0.5 \mathrm{mb}$ of $\mathrm{S} / \mathrm{N} 34$ during the whole comparison period and within $0.5 \mathrm{mb}$ of the Paroscientific from day 308 .

AIR S/N 58, Figures 9, 10: This sensor had a complete upgrade in 1986 and was recalibrated in June 1989 during a repair to the digital board (WHOI-caused). Since the digital board does not affect the calibration constants, this can be considered a regular calibration. The figure shows that for well over a year the barometer was stable and agreed with $\mathrm{S} / \mathrm{N} 34$ within $0.4 \mathrm{mb}$. During the last month of the comparison it was used in a pressure cycling study which may be the cause of the instability apparent on the plot. That study will continue for several more weeks after which we will determine if the cycling or applying the power intermittently caused the problem.

AIR S/N 67, Figures 11, 12: This barometer has a history of very serious drift problems. Its analog board was replaced by AIR in an attempt to correct it but continued drift after the repair is quite apparent. It has now been returned to AIR for another repair. It seems likely that the evacuated cell will be replaced next.

AIR S/N 70, Figures 13, 14: This barometer also has had serious drift problems. Replacement of the analog board in January 1989 seems to have cured the drift, but the $0.5 \mathrm{mb}$ bias after the recalibration is an anomaly.

AIR S/N 80, Figures 15, 16: Experience with this barometer is very similar to that with S/N 70. The serious drift problem seems to have been cured by the 
replacement of the analog board in January 1989, but S/N 80 also had a bias of $0.5 \mathrm{mb}$ when it was returned after the repair and recalibration.

AIR S/N 115, Figures 17, 18: This barometer had a thorough upgrade in 1987 and was recalibrated in June 1989. Its performance has been excellent with little drift. The difference with $\mathrm{S} / \mathrm{N} 34$ has remained within $0.3 \mathrm{mb}$ for well over a year. After the June 1989 recalibration, we started a pressure cycling test on it (as on S/N 58). The readings have been erratic since then, but determination of the cause will be attempted at the end of the cycling test.

AIR S/N 197, Figures 19, 20: After about three months of monitoring we accidentally put a transient pressure into S/N 197 which caused it to fail. Its drift rate before then had been about $-1 \mathrm{mb} / \mathrm{yr}$, higher than AIR's specifications. After replacement of the cell and recalibration, it agreed well with $\mathrm{S} / \mathrm{N} 34$ but it still seems to be drifting at the same rate.

\subsection{April 1989 to Present}

During this period we added to the AIRs and the Paroscientific $760-15 \mathrm{~A}$ already being monitored two Paroscientific Model 760-15A, two Rosemount Model 1201F1B, two Setra Model 270, and two Heise Model 623 barometric pressure sensors. All the newly-added sensors have had power applied to them continuously during the four months of their comparison period.

We have used the Paroscientific 760-15A portable standard as the base of comparison since it seemed to be the best of any of the sensors in our suite. Since change in the difference between the reading of an individual sensor and the Paroscientific appears to vary linearly with time where there is a significant drift, we have made a linear least squares fit between the pressure difference and year day. Table 3 sums up the observed drift rates extrapolated from the four month data period to one year. 
In the next few paragraphs we will comment on the individual sensors.

Paroscientific Model 215-AT, Figures 21, 22: From Table 3 we see that the Paroscientific sensors had extremely low drift rates and biases when compared to the Model 760-15A. All three Paroscientifics are certainly consistent with each other and are probably the most accurate sensors in the study.

Rosemount Model 1201F1B, Figures 23, 24: The Rosemount has a DC voltage output linear in pressure, $0-5 \mathrm{~V}$ for $900-1050 \mathrm{mb}$. Its temperature correction is by internal analog circuitry so it could be calibrated in our calibration facility with a sufficiently accurate pressure transfer standard such as, perhaps, the Paroscientific 760-15A.

The performance of the Rosemount is excellent. The 12-month extrapolated drift probably includes zero within the error bars for both sensors because of the scatter in the data and the four month data period.

Setra Systems Model 270, Figures 25, 26: The Setra output is a DC voltage, linear in pressure, $0-5 \mathrm{~V}$ for $800-1100 \mathrm{mb}$. Temperature correction is by internal analog circuitry. As for the Rosemount, we could calibrate this sensor in our facility.

The performance of these two sensors is definitely poorer than the Paroscientifics and Rosemounts. Assuming that "Full scale" is the $300 \mathrm{mb}$ difference between the range limits, Setra A is outside the manufacturer's specifications for long term drift and Setra B is barely within them. Shorter term fluctuations of order $0.1 \mathrm{mb}$ are apparent on the plots.

Heise Model 623, Figures 27, 28: The Heise output is linear, $0-5 \mathrm{~V}$ for 0-2000 mb input. The plots show a very high drift rate. We discussed the problem with a factory engineer and learned that there has been a problem with outgassing within the evacuated chamber. The sign and magnitude of the drift in our units is consistent with this. The manufacturer, Dresser Industries, is currently in the prototype stage of a new sensor with much tighter accuracy and drift specifications. 
Based on the performance in our comparison, we consider the Heise Model 623 unacceptable as a barometric pressure sensor.

\section{Summary and Conclusions}

Choice of a sensor for buoy applications usually involves trade-offs between accuracy, reliability, power consumption, and price. The Paroscientific Model 215-AT has probably the highest accuracy and stability of the sensors tested and it has, by at least an order of magnitude, the lowest power consumption. Its price, however, is the highest. The Rosemount Model 1201F1B also has excellent accuracy, but its power consumption is quite high, and its price is second only to the Paroscientific. The AIR DB-1A and the Setra Model 270 may have barely sufficient accuracy for our application, but the price and power consumption of each is moderate. The AIR's standby mode brings its power consumption down to extremely low values, and it has the advantage of delivering a digitized value. We have used AIRs for several years and can vouch for their reliability. Another group at WHOI has used the Paroscientifics extensively and has found them quite reliable. We have only the four months' experience with the others.

Thus, if you can afford it, the Paroscientific 215-AT is the clear choice. In the $\$ 1000$ price range the choice is less apparent. With either the AIR or the Setra it would be wise to purchase them well before a deployment and monitor their performance on shore for a few months.

We intend to continue this study and have an automatic logging system under construction. We have in house, and will log, sensors from Aanderaa and Vaisala. We will also include some inexpensive strain gauge sensors. 


\section{Acknowledgements}

The work described in this report was accomplished as part of the Improved Meteorology project (IMET) and funded by the National Science Foundation grant OCE-8709614. 
Table 1: Barometer Manufacturers' Specifications

\begin{tabular}{|c|c|c|c|c|c|c|}
\hline & $\begin{array}{c}\text { PARO } \\
760-15 \mathrm{~A}\end{array}$ & $\begin{array}{l}\text { PARO } \\
215-A T\end{array}$ & $\begin{array}{c}\text { AIR } \\
\text { DB-1A }\end{array}$ & $\begin{array}{c}\text { ROSE } \\
1201 \mathrm{~F} 1 \mathrm{~B}\end{array}$ & $\begin{array}{c}\text { SETRA } \\
270 \\
\end{array}$ & $\begin{array}{l}\text { HEISE } \\
623 \\
\end{array}$ \\
\hline Output Range & $0-1040 \mathrm{mb}$ & $40-36 \mathrm{kHz}$ & $0-1300 \mathrm{mb}$ & $0-5 \mathrm{VDC}$ & $0-5 \mathrm{VDC}$ & 0-5 VDC \\
\hline Pressure Range (mb) & $0-1040$ & $0-1040$ & $0-1300$ & $900-1050$ & $800-1100$ & $0-2000$ \\
\hline Sensitivity/Resolution & $.01 \mathrm{mb}$ & $3.9 \mathrm{~Hz} / \mathrm{mb}$ & $.01 \mathrm{mb}$ & $33 \mathrm{mv} / \mathrm{mb}$ & $17 \mathrm{mv} / \mathrm{mb}$ & $2.5 \mathrm{mv} / \mathrm{mb}$ \\
\hline Linearity & $.005 \% \mathrm{FS}$ & $.005 \% \mathrm{FS}$ & & $.03 \% \mathrm{FS}$ & $.05 \% \mathrm{FS}$ & \\
\hline Hysteresis & $.005 \% \mathrm{FS}$ & $005 \% \mathrm{FS}$ & & $.005 \% \mathrm{FS}$ & $.01 \% \mathrm{FS}$ & \\
\hline Repeatability & $.005 \% \mathrm{FS}$ & $.005 \% \mathrm{FS}$ & & $.005 \% \mathrm{FS}$ & $.01 \% \mathrm{FS}$ & $.005 \% \mathrm{FS}$ \\
\hline Thermal coeff. & & & & & $.002 \% \mathrm{FS} / \mathrm{C}$ & $.02 \% \mathrm{FS} / \mathrm{C}$ \\
\hline Accuracy & $.01 \% \mathrm{FS}$ & $.01 \% \mathrm{FS}$ & $.5 \mathrm{mb}$ & $.031 \% \mathrm{FS}$ & $.05 \% \mathrm{FS}$ & $.15 \% \mathrm{FS}$ \\
\hline Long term stability $(/ \mathrm{yr})$ & & & $.3 \mathrm{mb}$ & $.23 \% \mathrm{FS}$ & $.2 \% \mathrm{FS}$ & $.2 \% \mathrm{FS}$ \\
\hline Temperature Range (C) & $-54-107$ & $-54-107$ & $-30-50$ & $-20-50$ & $-18-80$ & $-18-65$ \\
\hline Power Supply & & $12 \mathrm{mw}$ & $50 \mathrm{mw}$ & $780 \mathrm{mw}$ & $192 \mathrm{mw}$ & $1000 \mathrm{mw}$ \\
\hline $\begin{array}{l}\text { Voltage } \\
\text { (VDC unless noted) }\end{array}$ & $115 \mathrm{VAC}$ & $6-35$ & +8 to 16 & 12 & 24 & $20-40$ \\
\hline Current & & $2 \mathrm{ma}$ & $\begin{array}{l}6.3 \text { ma oper. } \\
.01 \text { ma stdby }\end{array}$ & 65 & 8 & 50 \\
\hline Price & $\$ 3695$ & $\$ 2455$ & $\$ 1000$ & $\$ 1835$ & $\$ 955$ & $\$ 870$ \\
\hline Factory recalibration & $\$ 290$ & $\$ 290$ & $\$ 100$ & $\$ 250$ & $\$ 90$ & \\
\hline
\end{tabular}


Table 2: S/N 34 Comparisons with Newly Calibrated AIRs

\begin{tabular}{rccl}
$\mathrm{S} / \mathrm{N} \mathrm{X}$ & $\mathrm{X}-34$ & $\begin{array}{c}\text { Day Returned } \\
\text { To Comparison }\end{array}$ & AIR Action \\
\hline 44 & $+0.05 \mathrm{mb}$ & 220 & Verify calibration \\
58 & $+0.2 \mathrm{mb}$ & 220 & Verify calibration \\
197 & $0.0 \mathrm{mb}$ & 480 & Recalibration \\
58 & $+0.1 \mathrm{mb}$ & 560 & Recalibration \\
\hline
\end{tabular}

Table 3: Sensor Drift Rates

\begin{tabular}{lc} 
Sensor & Drift Rate \\
\hline Paroscientific A & -0.03 \\
Paroscientific B & -0.04 \\
Rosemount A & 0.01 \\
Rosemount B & -0.19 \\
Setra A & -1.07 \\
Setra B & -0.55 \\
Heise A & -19.7 \\
Heise B & -18.5 \\
\hline
\end{tabular}




\section{Appendix - Manufacturer's Addresses}

Atmospheric Instrumentation Research, Inc.

8401 Baseline Road

Boulder, Colorado 80303

(303) 499-1701

Dresser Industries, Inc. (Heise sensors)

Newtown Plant, Route 25

Newtown, Connecticut 06470

(203) 426-3115

Paroscientific, Inc.

4500 148th Avenue N.E.

Redmond, Washington 98052

(206) $883-8700$

Rosemount, Inc.

14300 Judicial Road

Burnsville, Minnesota 55337

(612) $435-4000$

Setra Systems, Inc.

45 Nagog Park

Acton, Massachusetts 01720

(617) $263-1400$ 


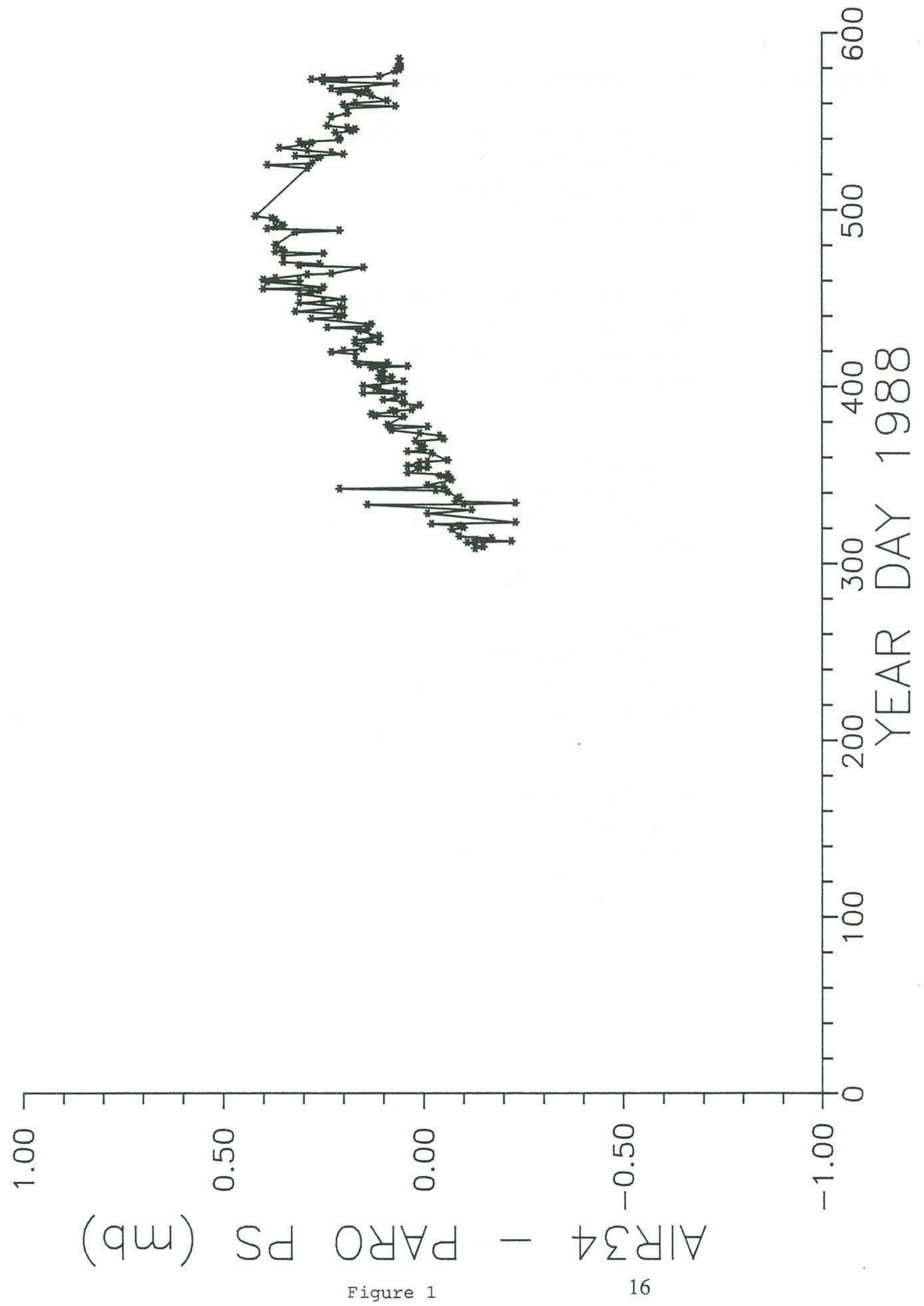




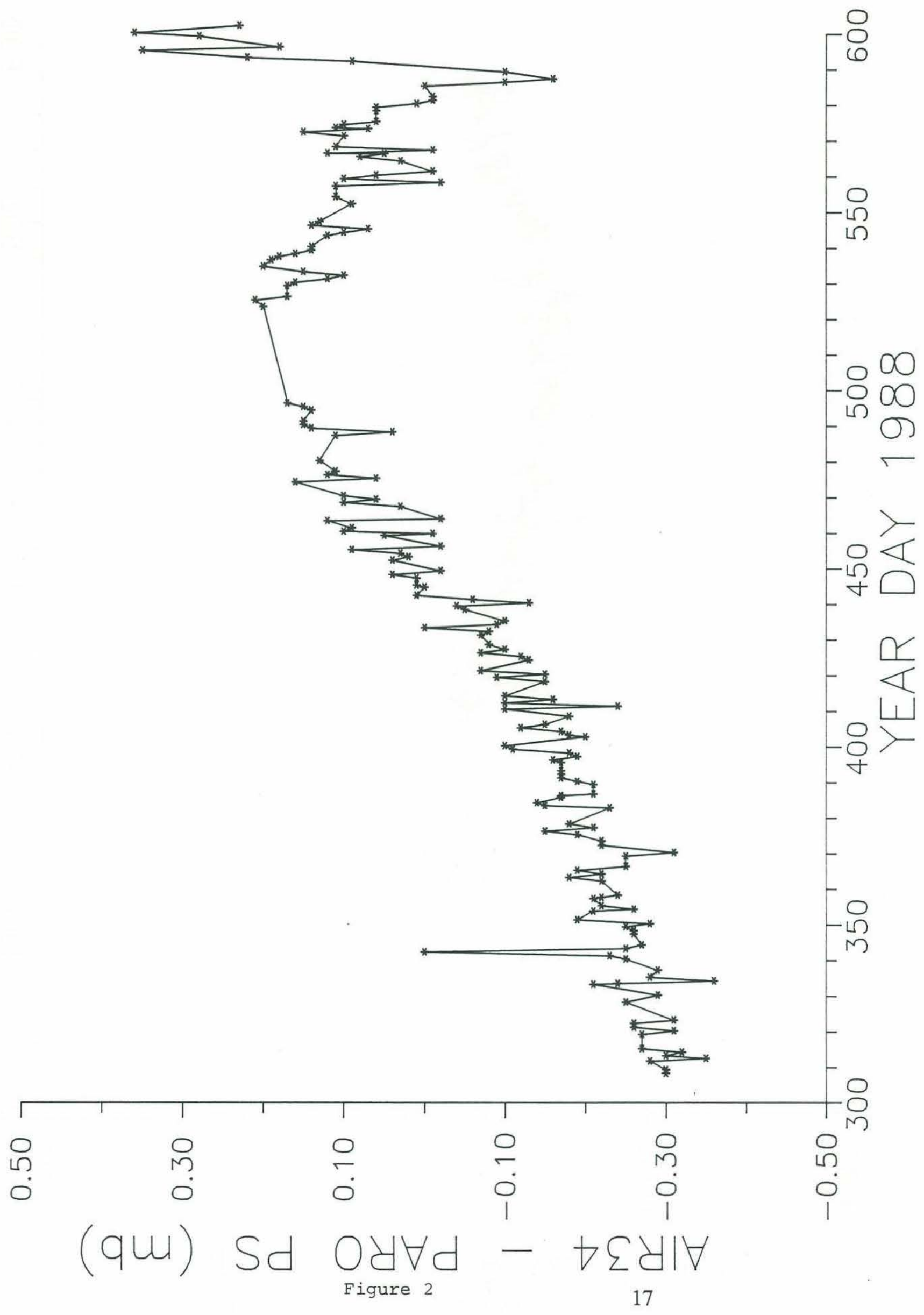




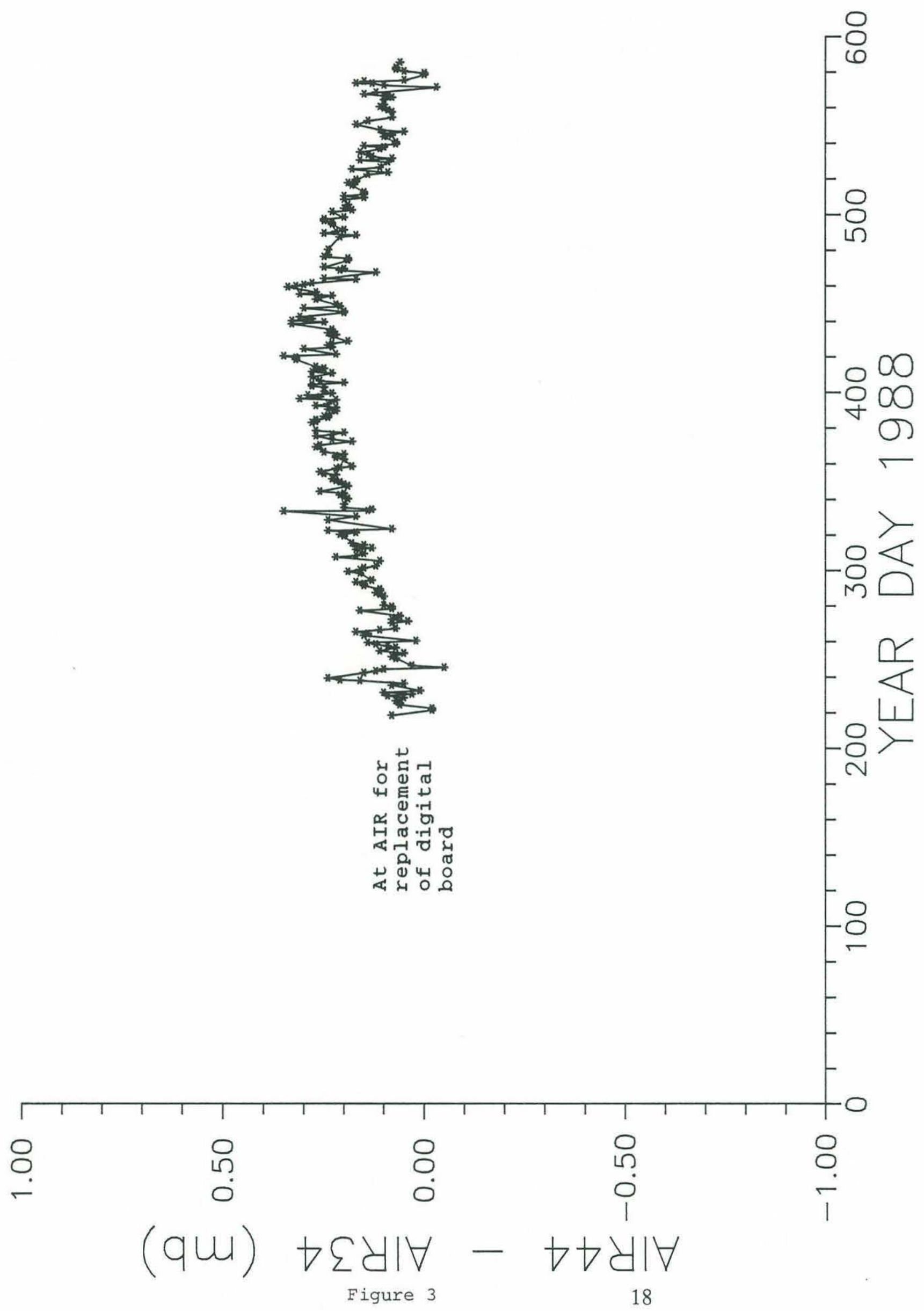




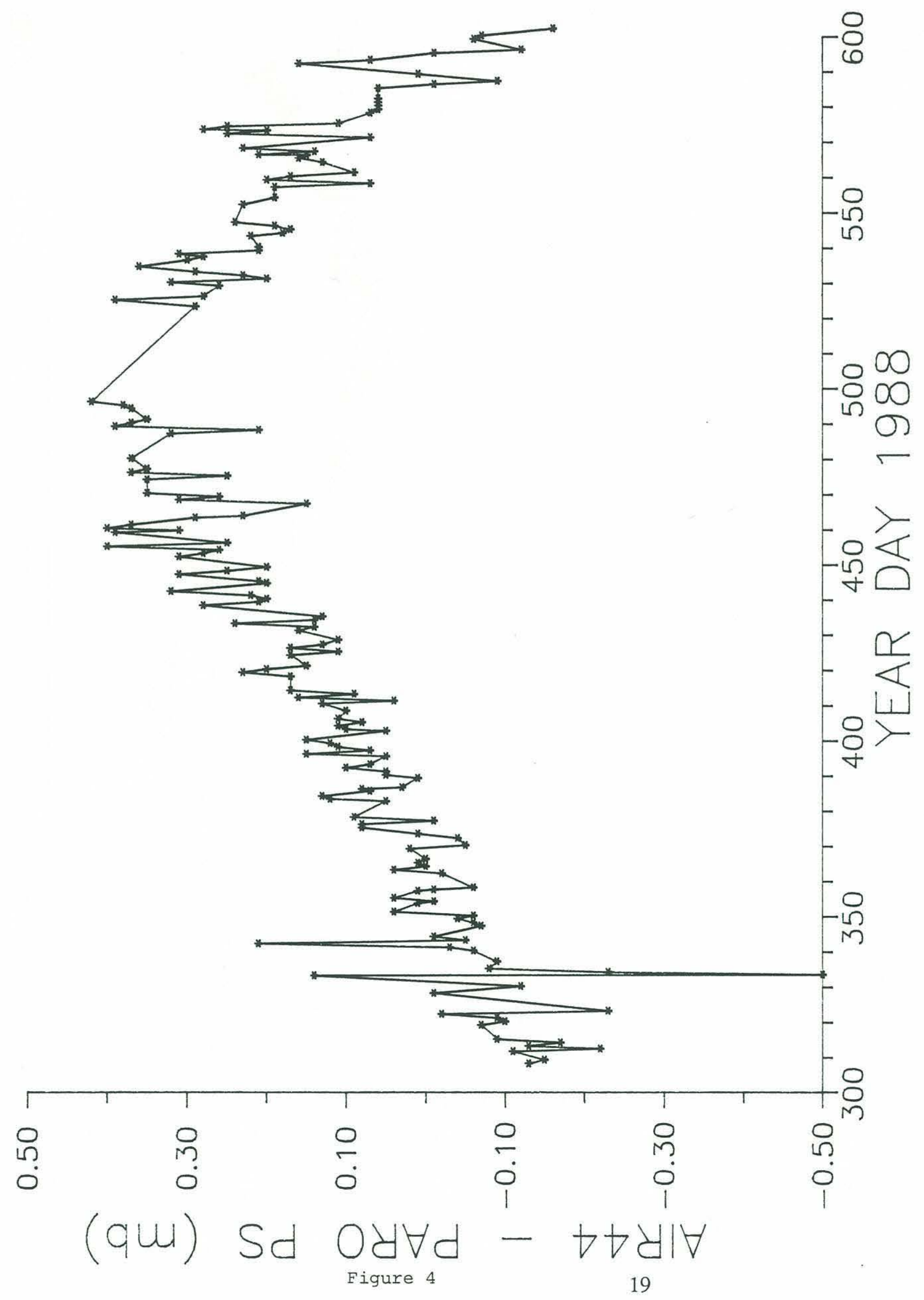




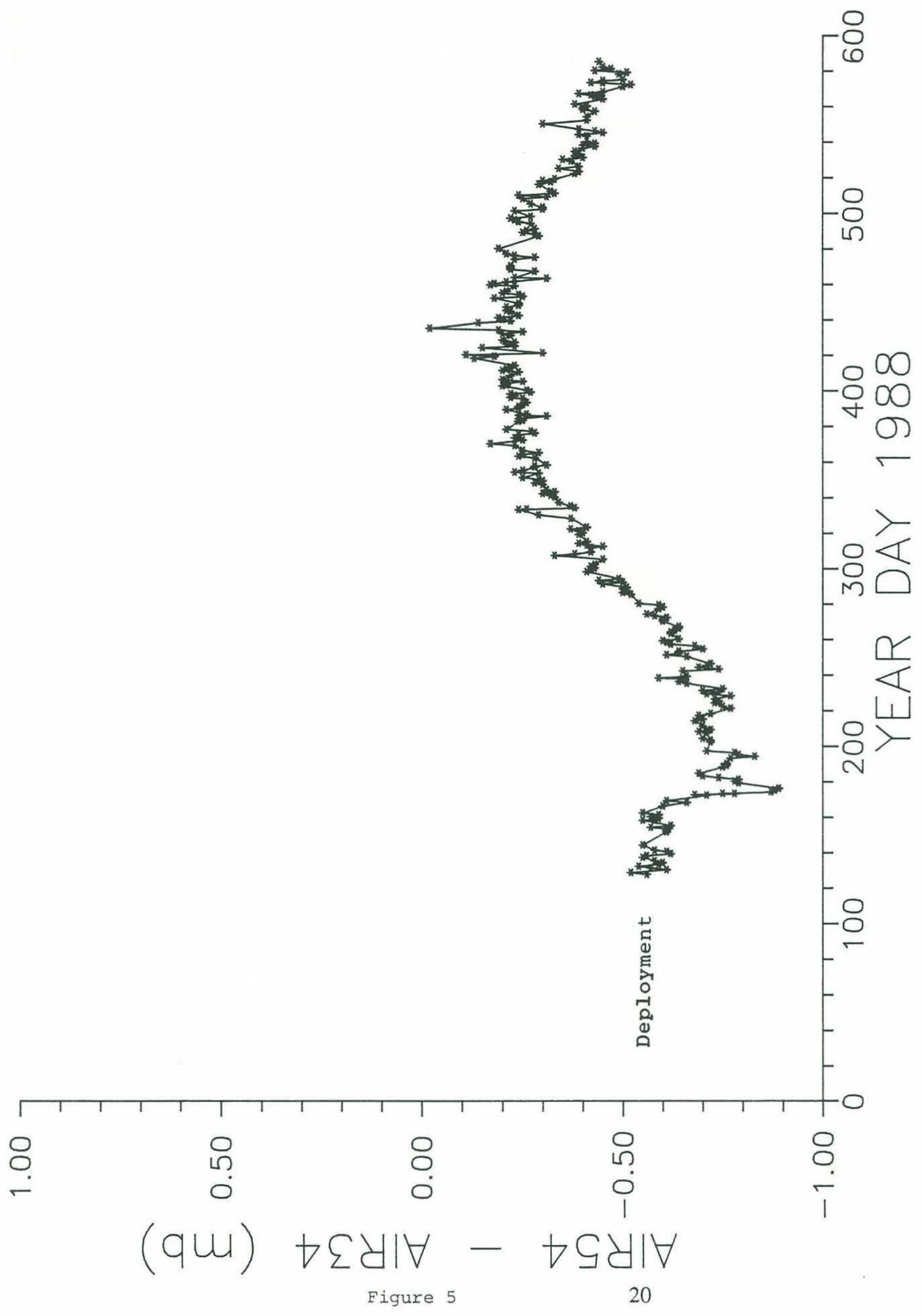




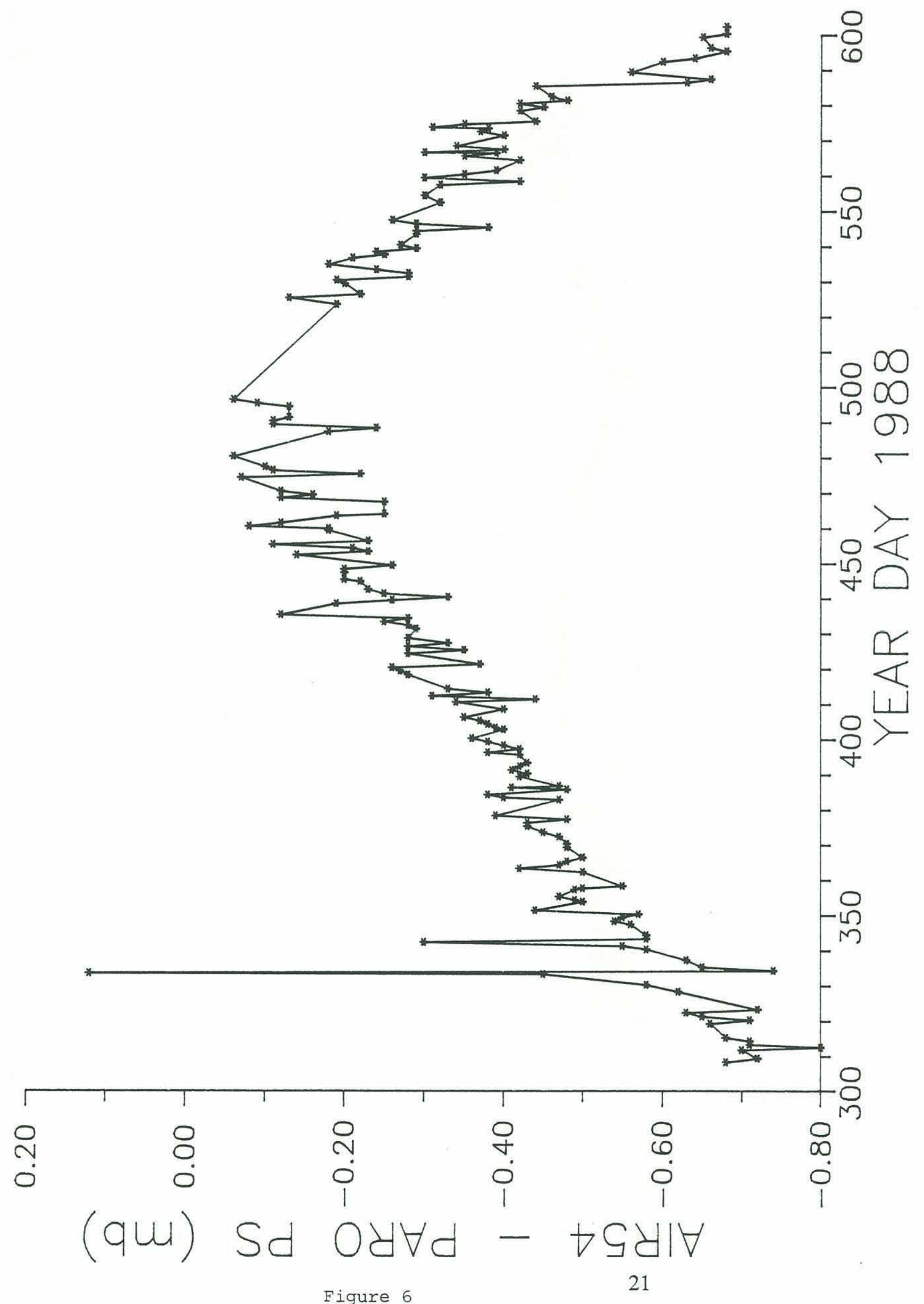




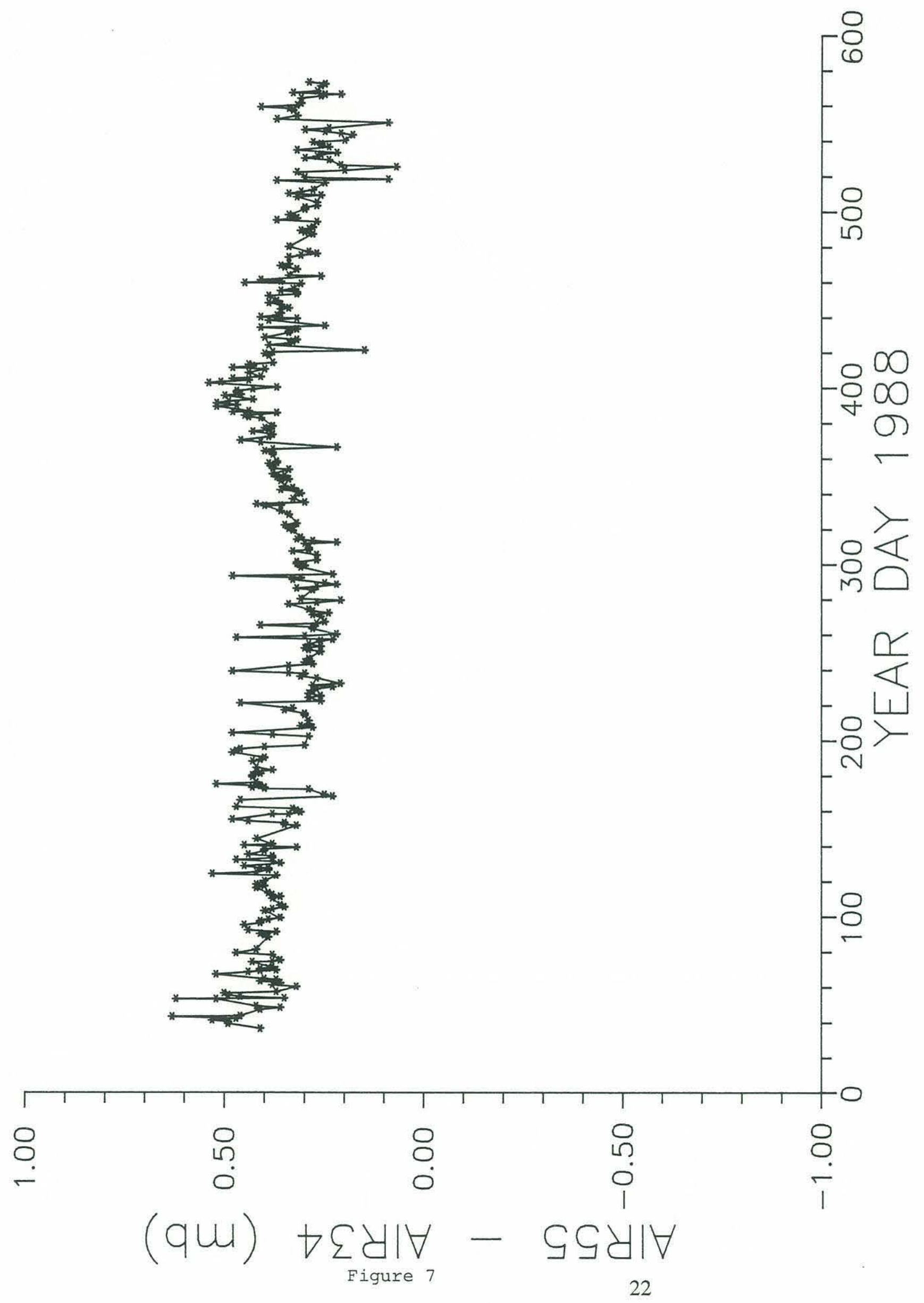




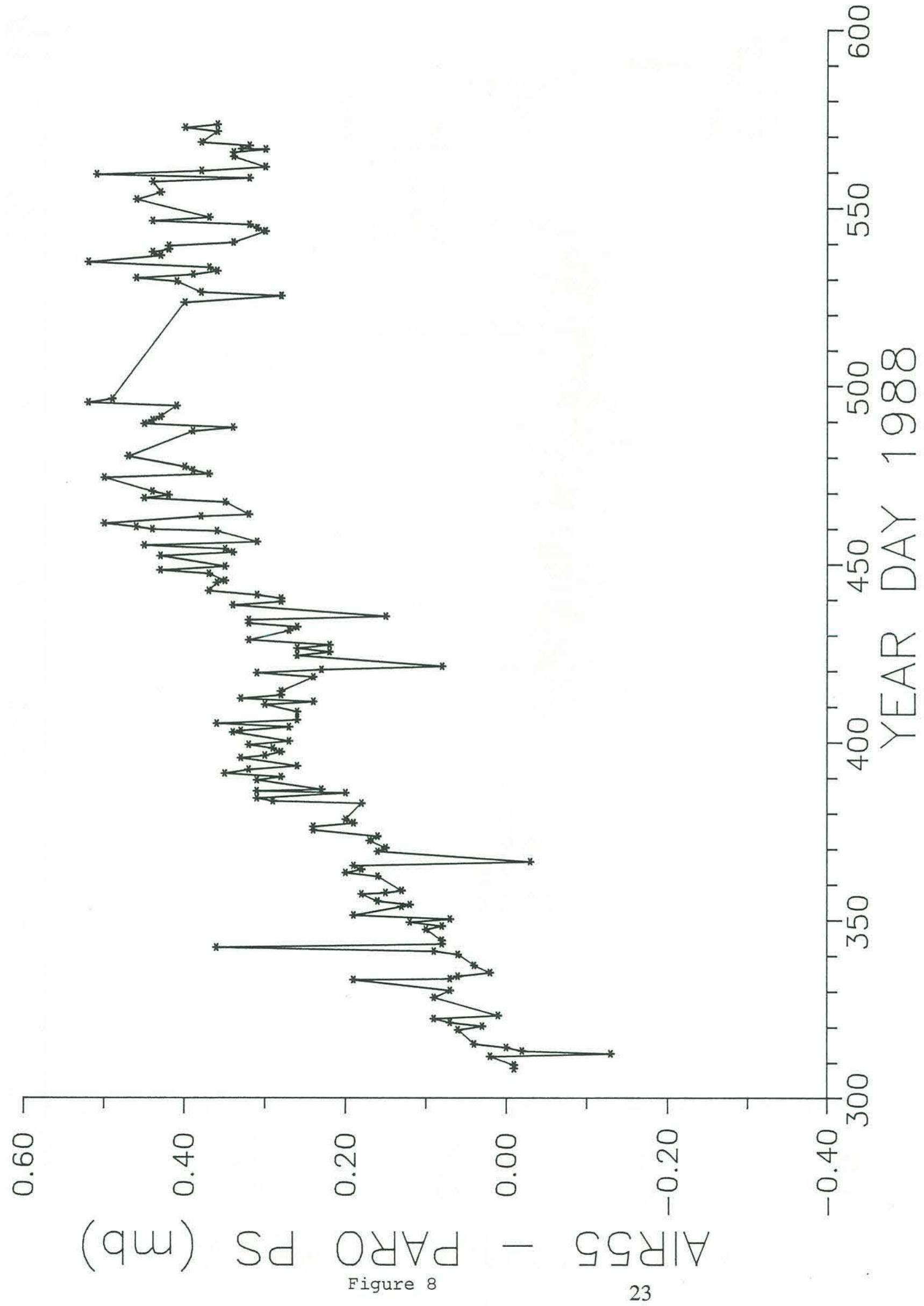




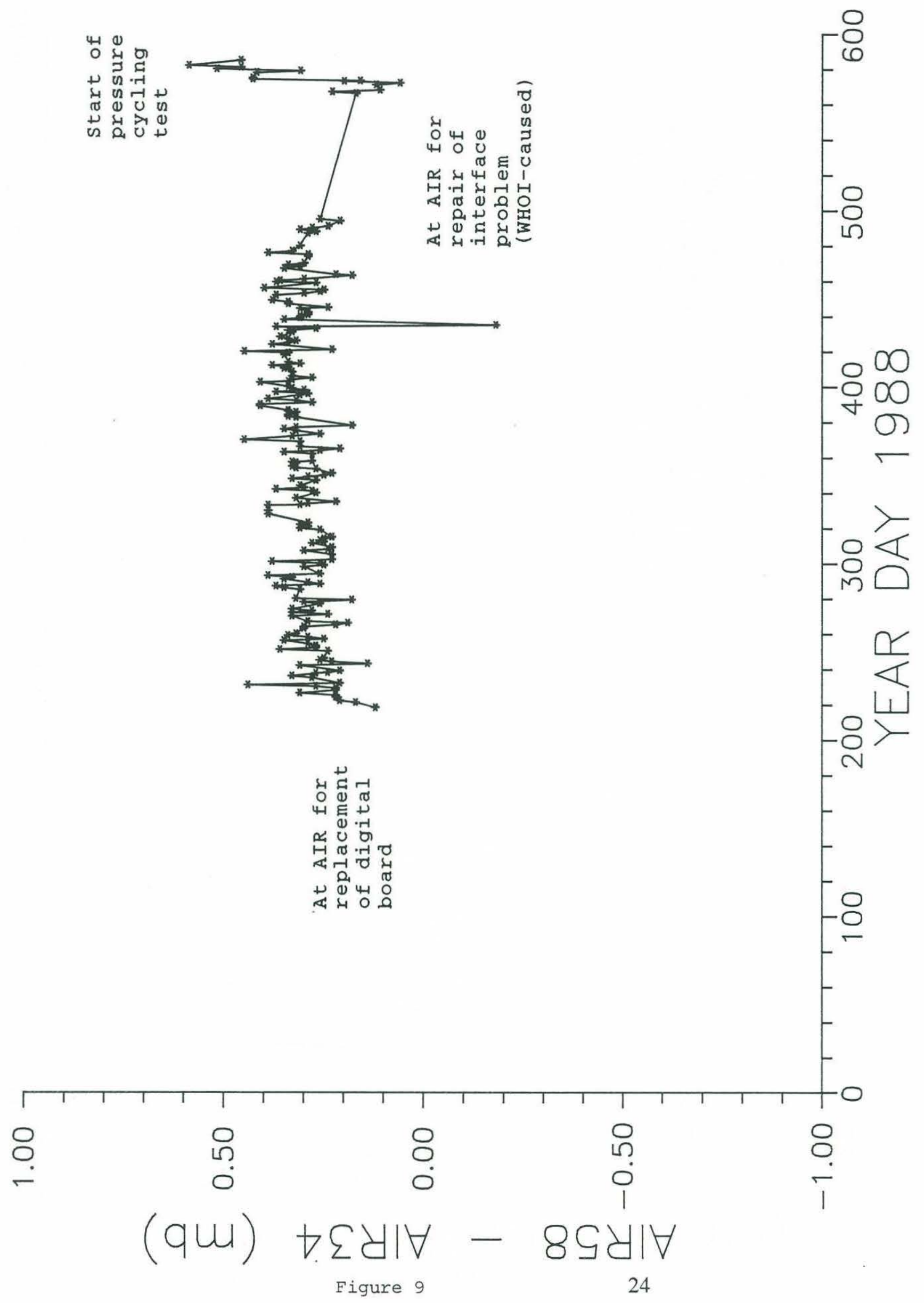




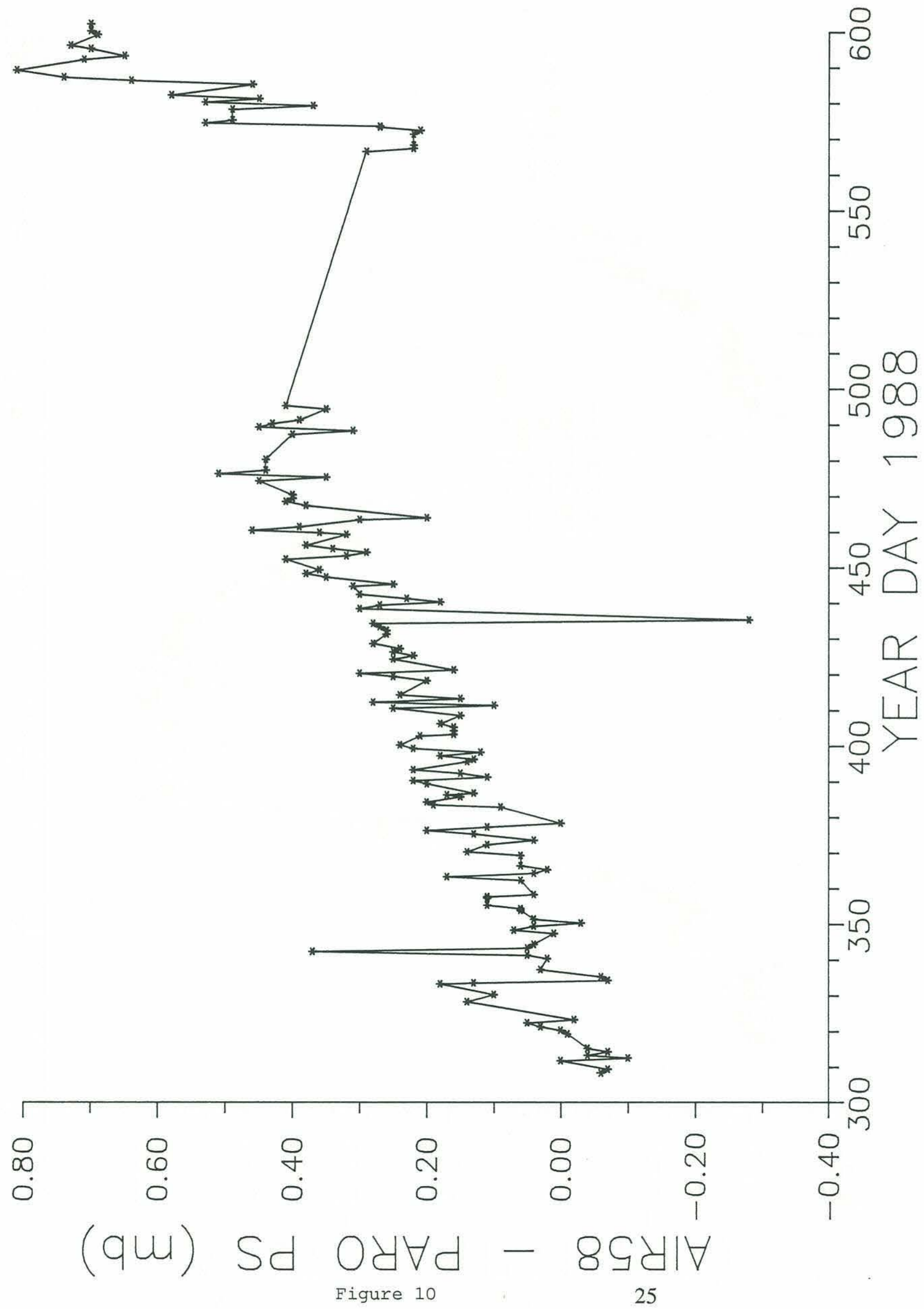




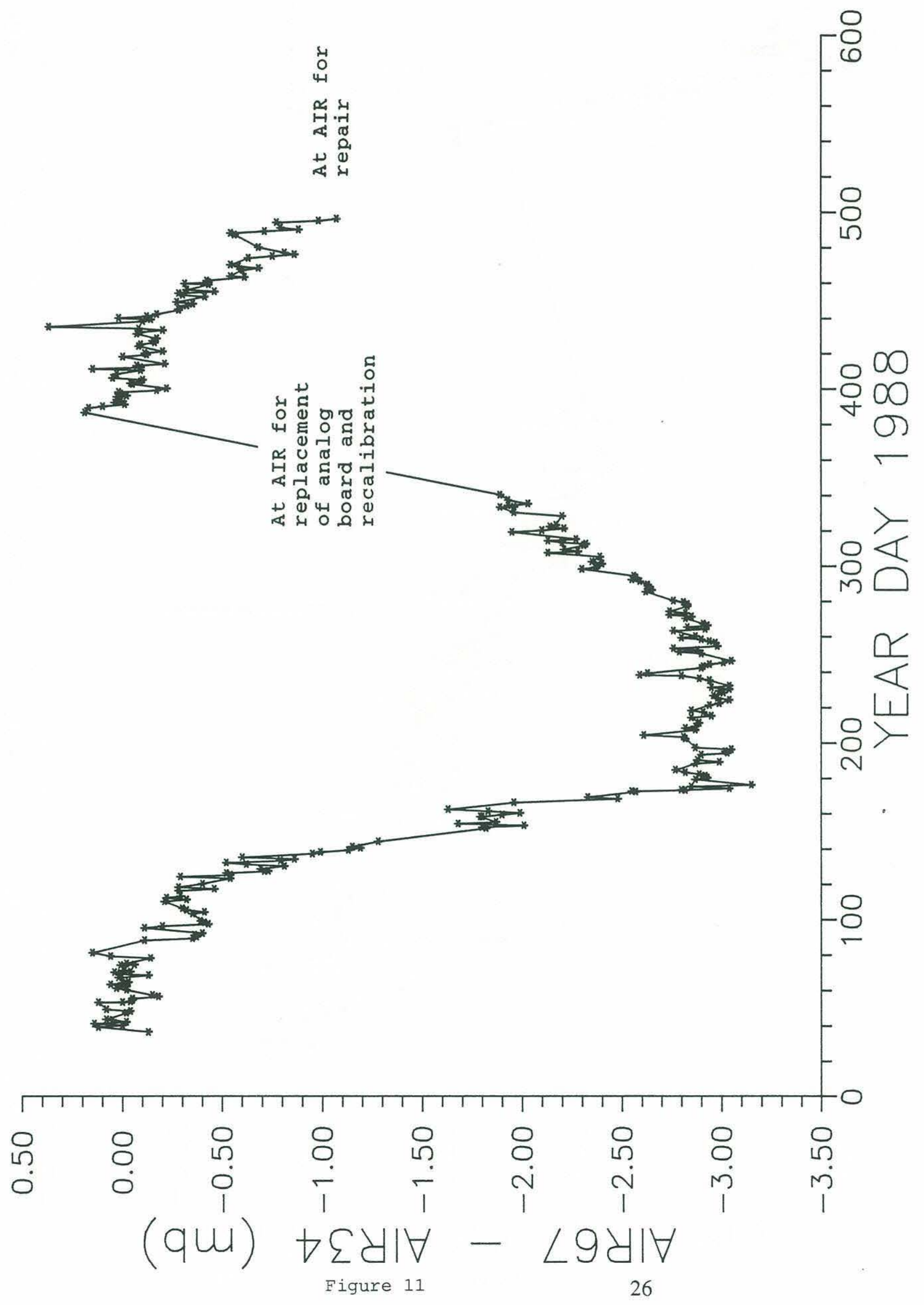




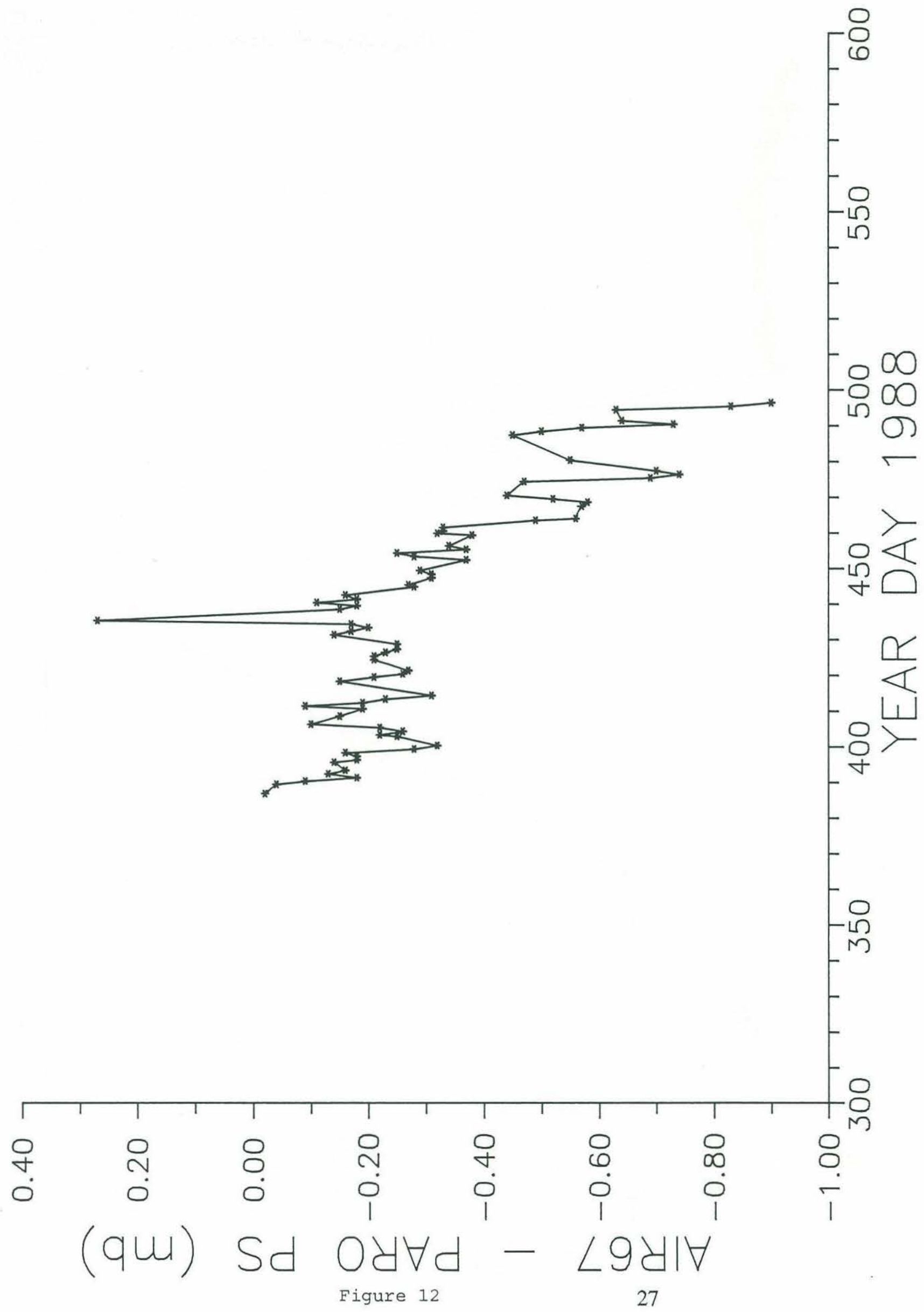




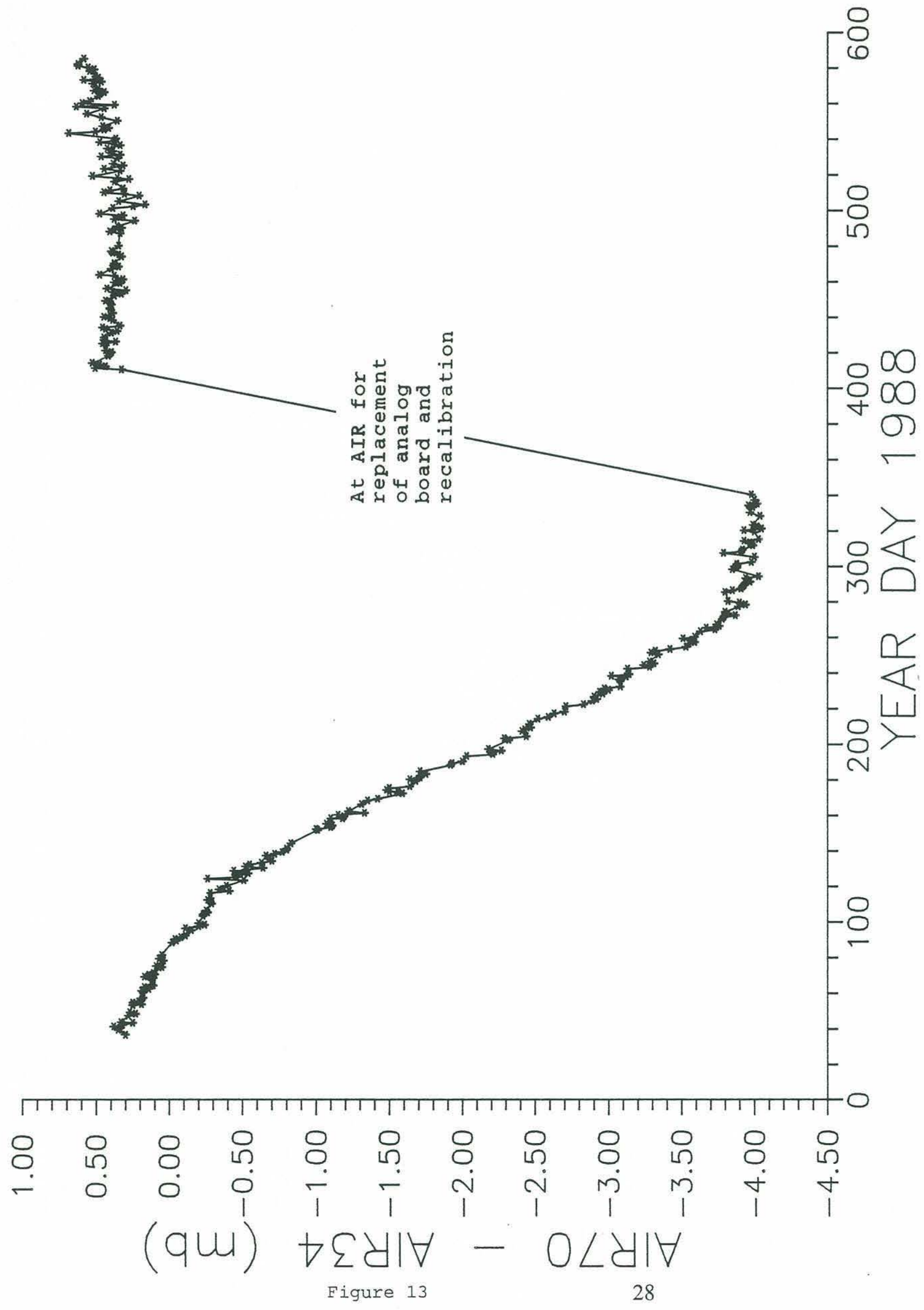




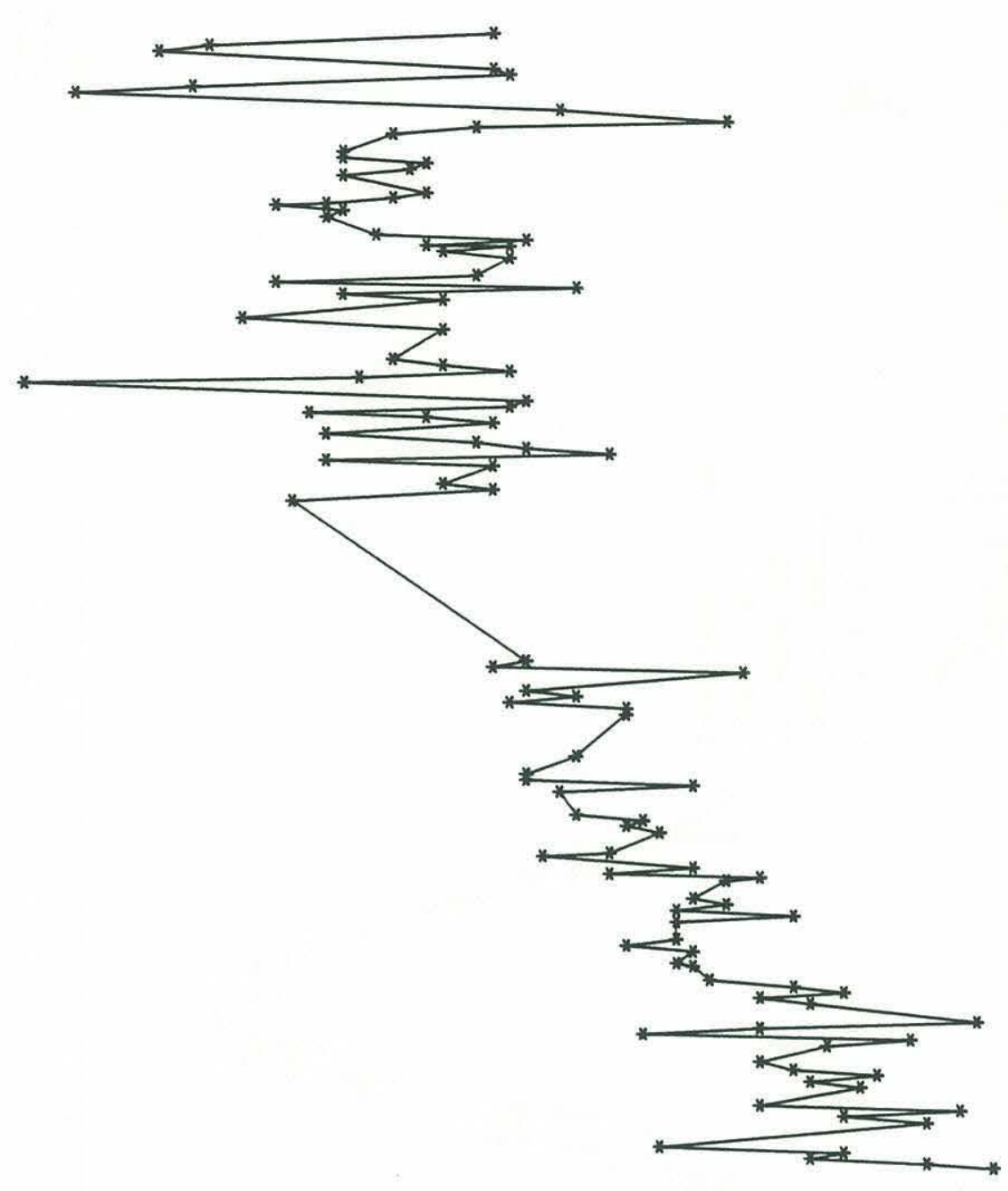

0
6 


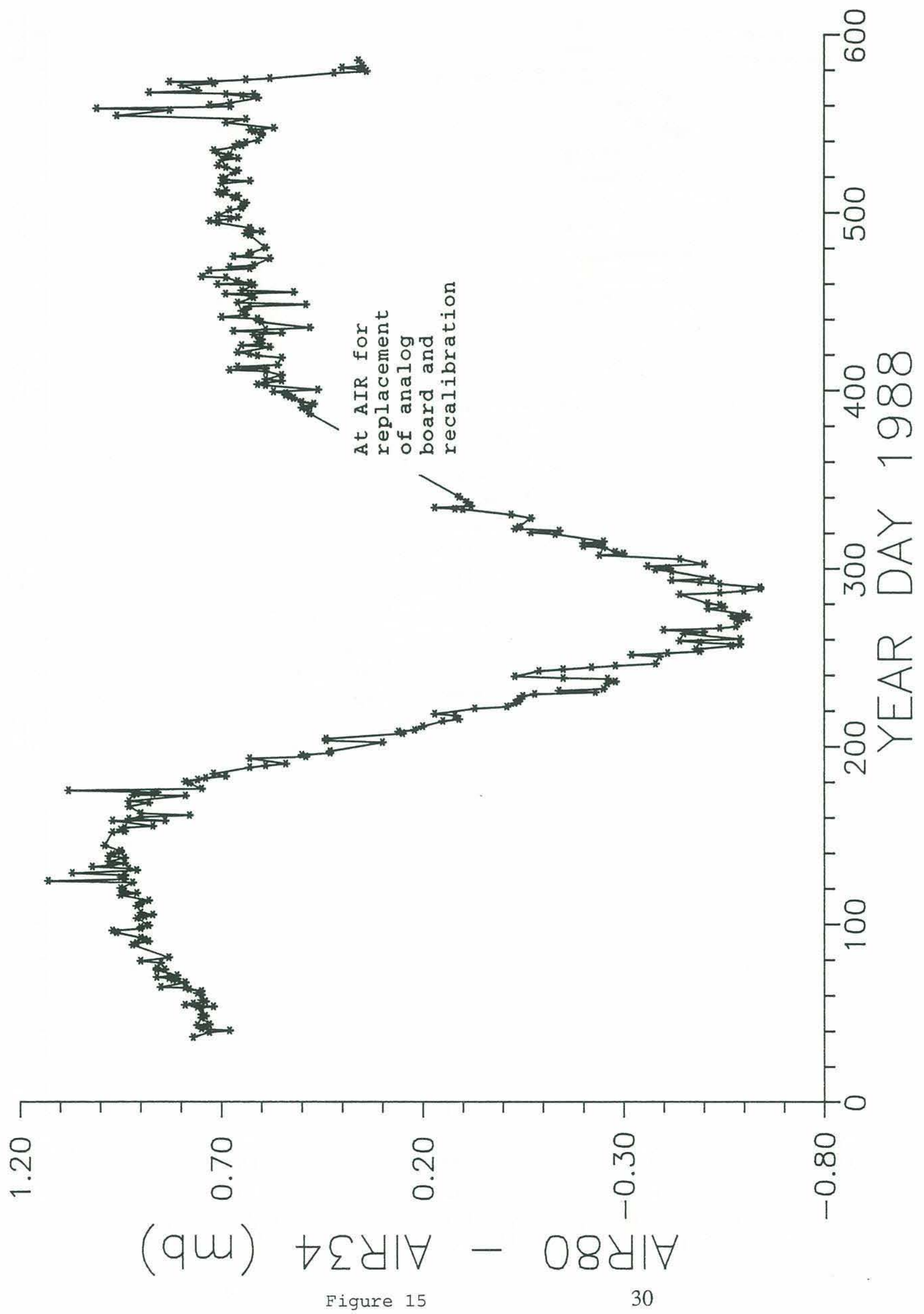




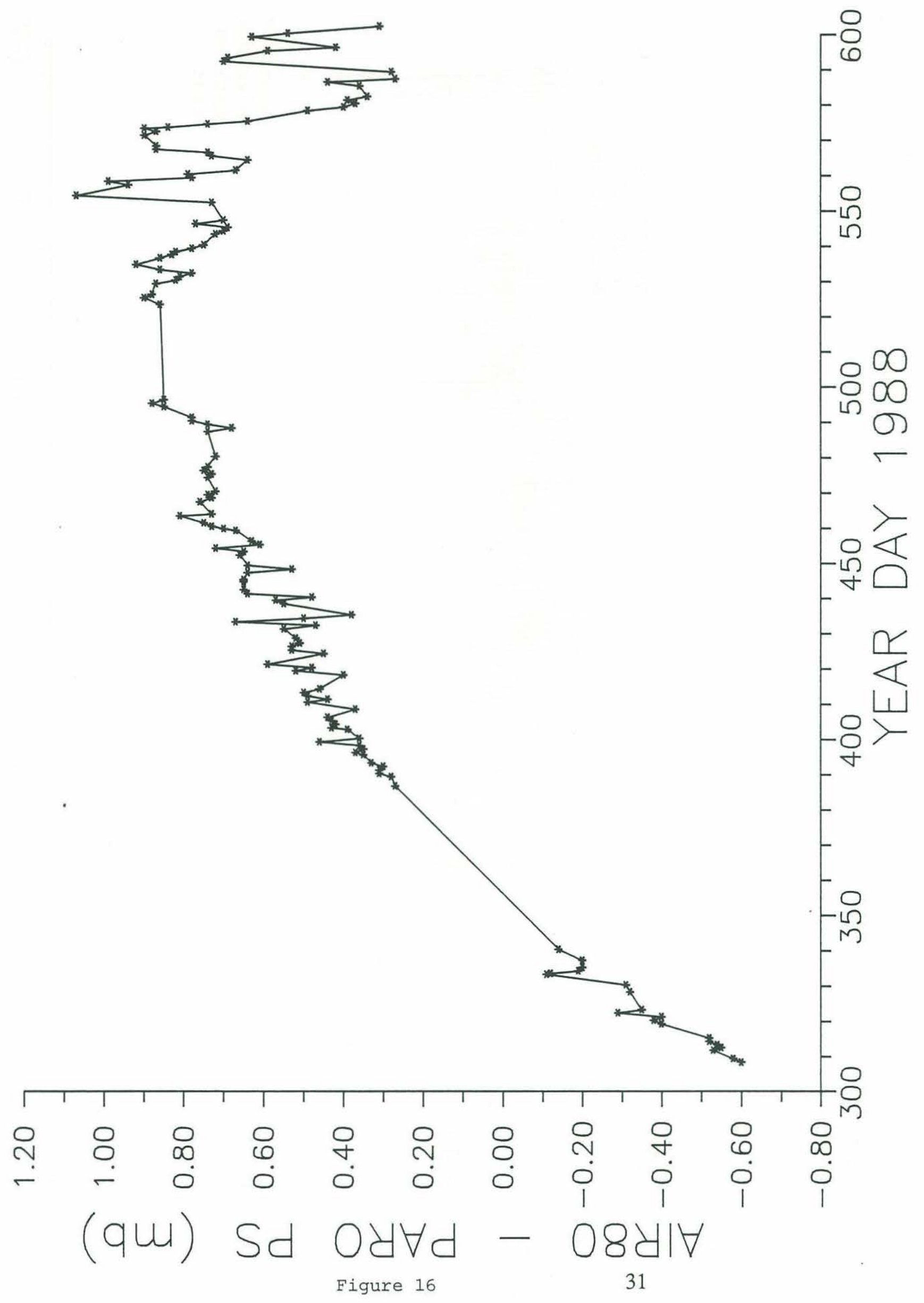




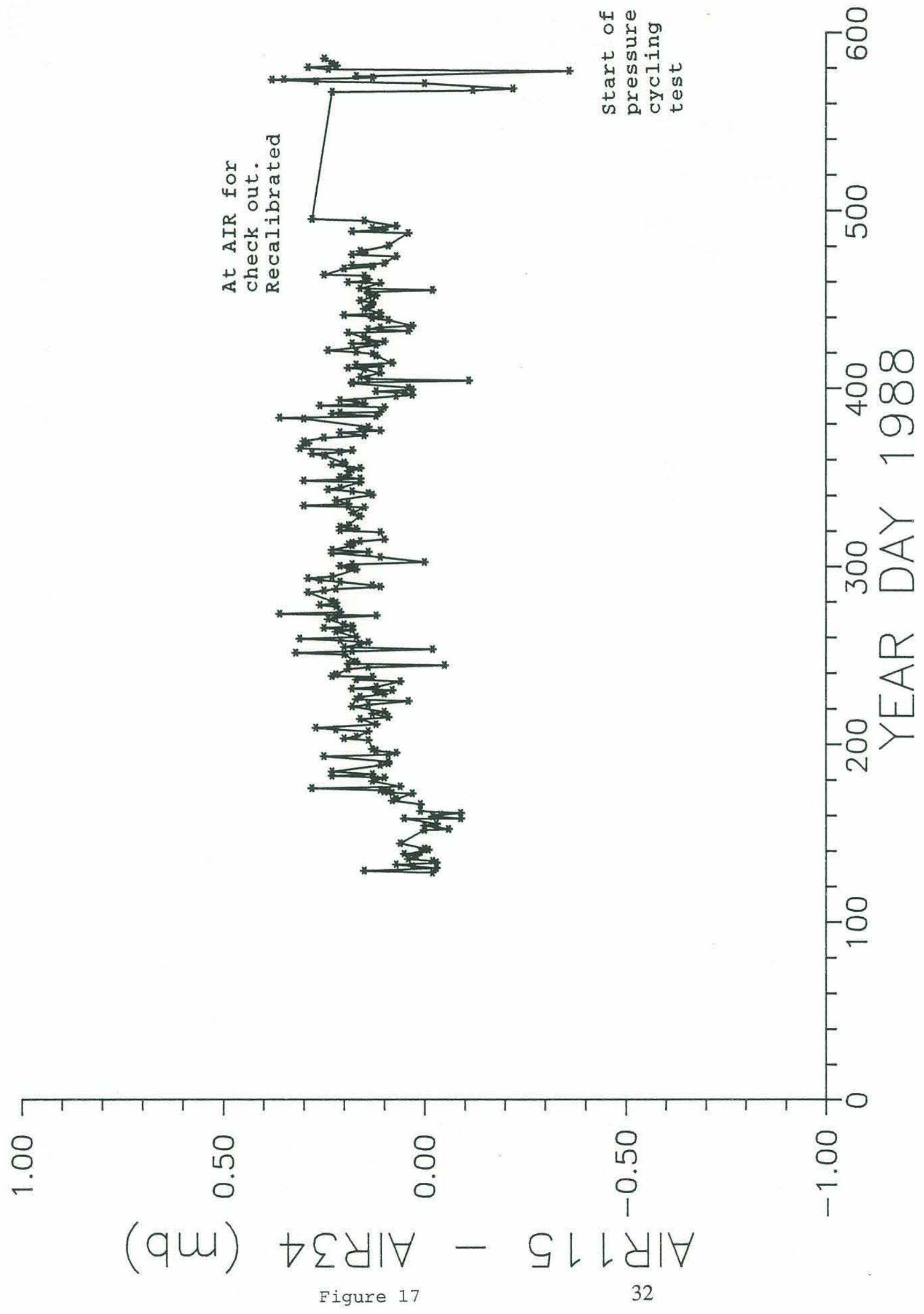




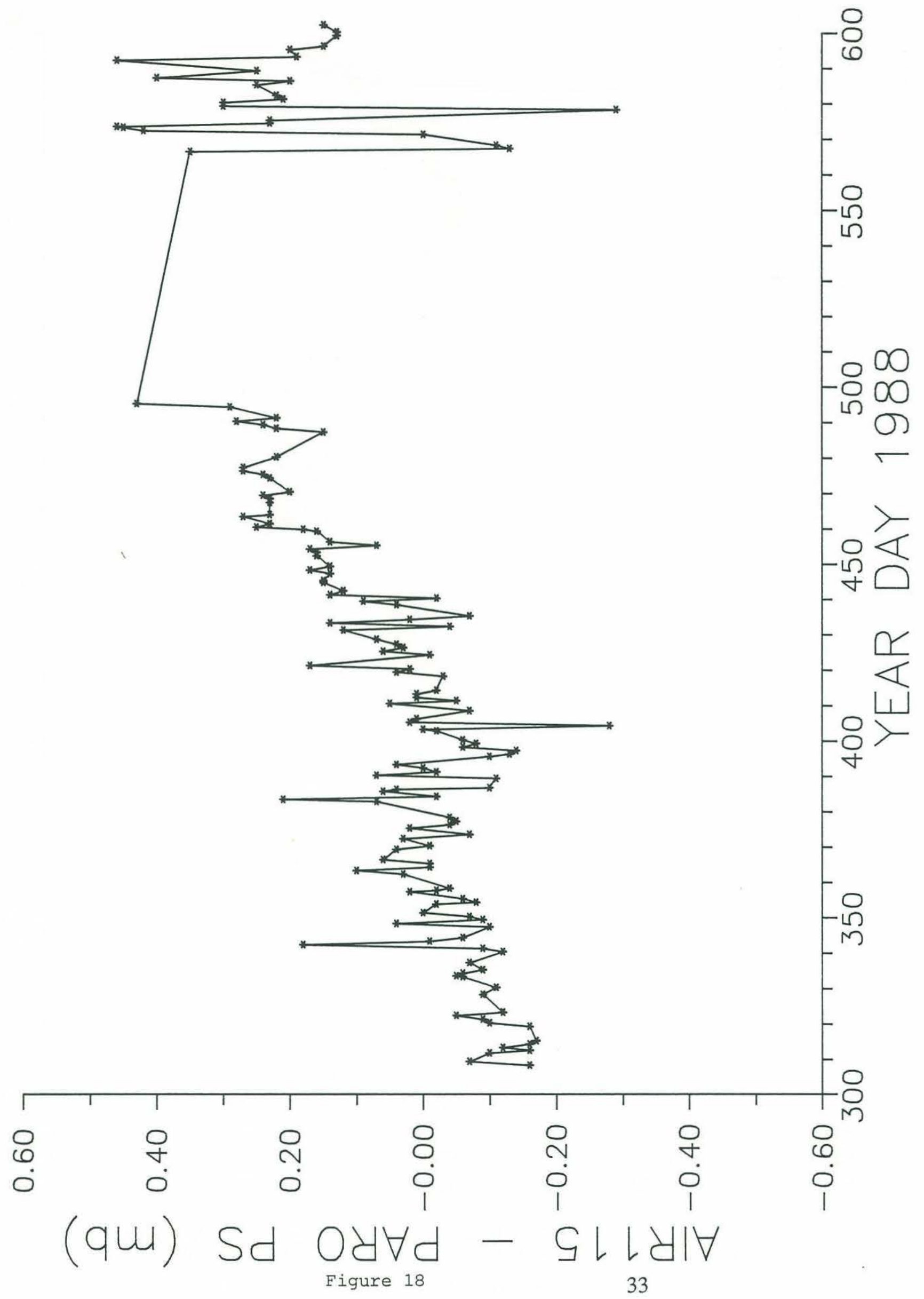




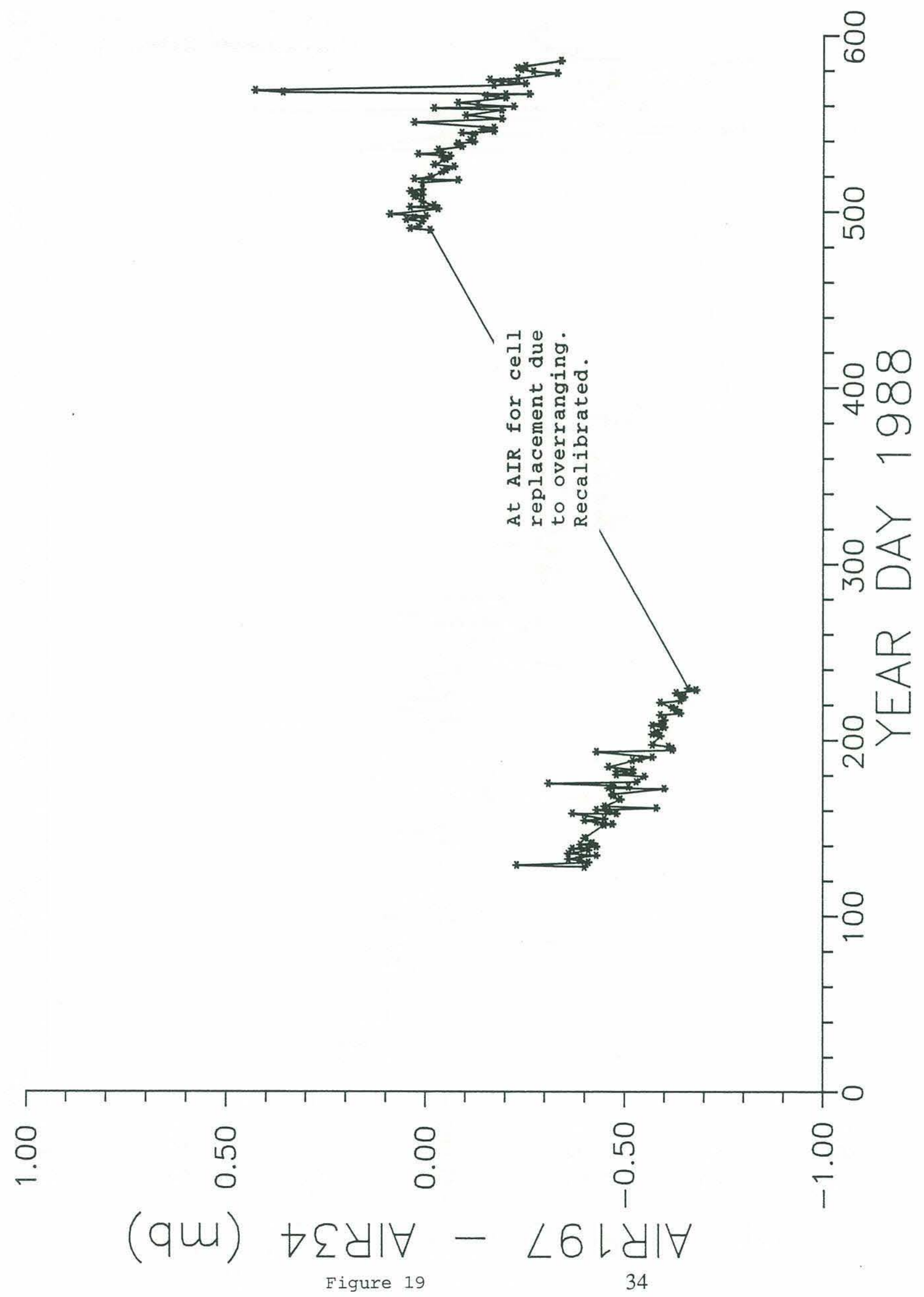




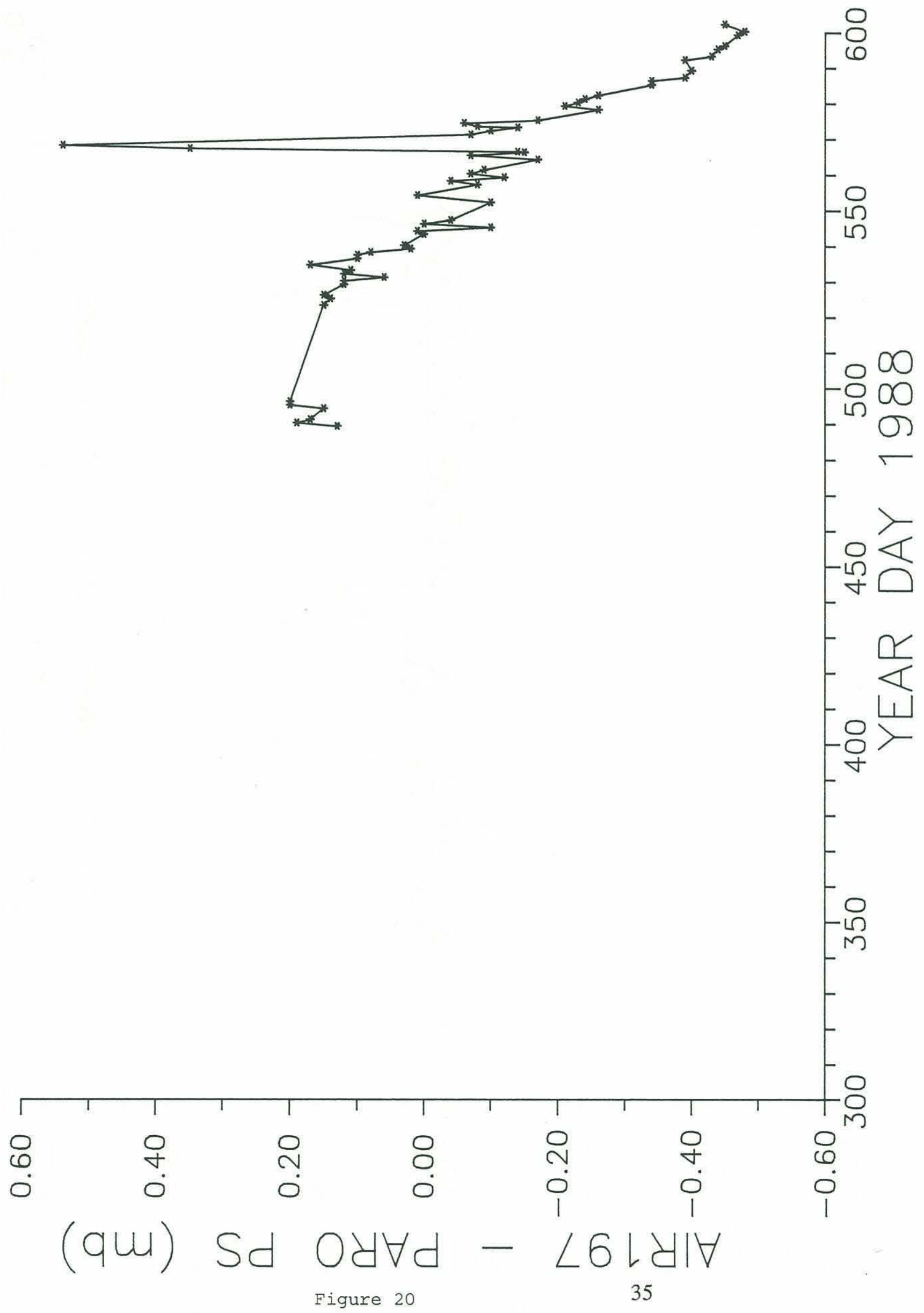




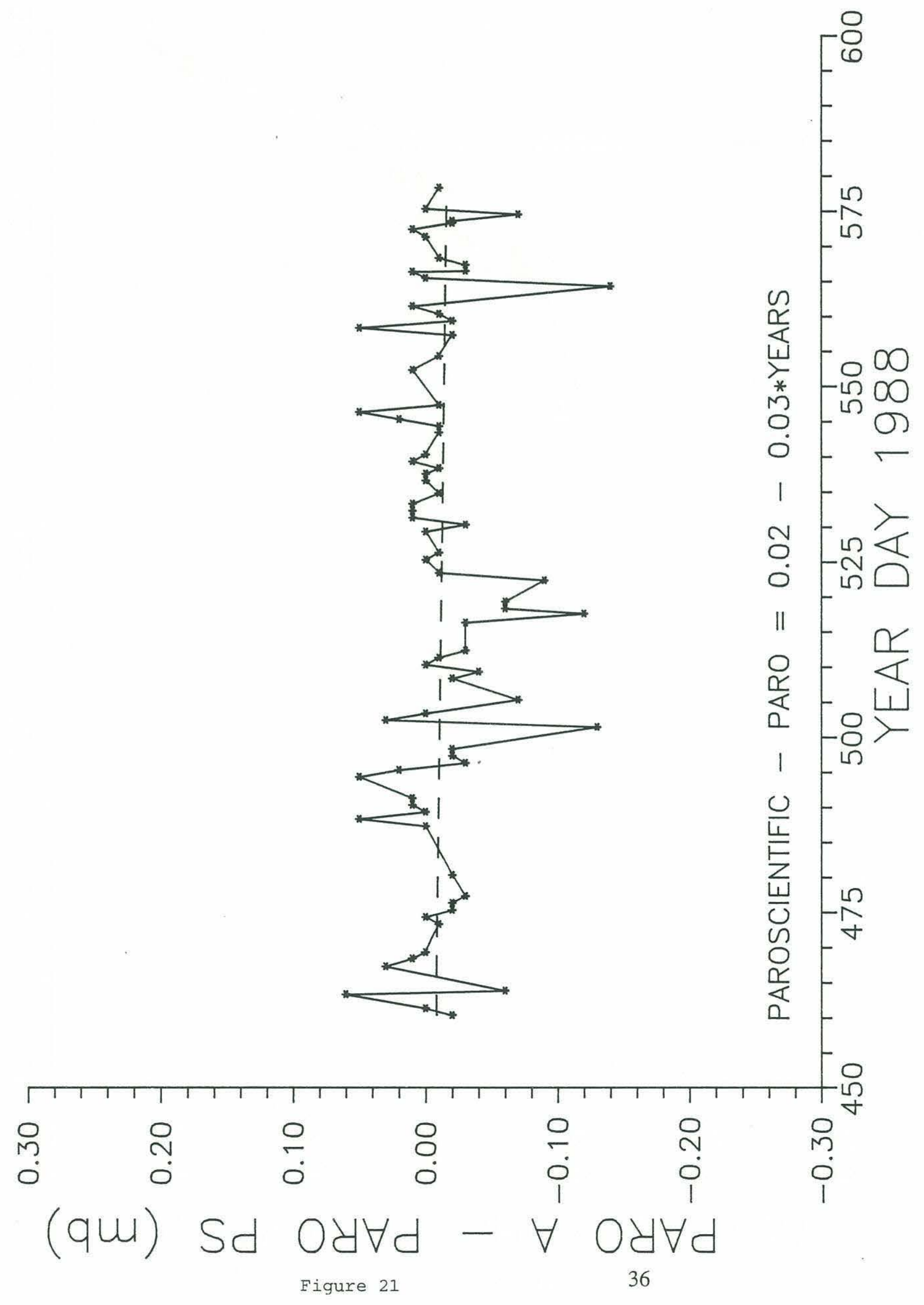




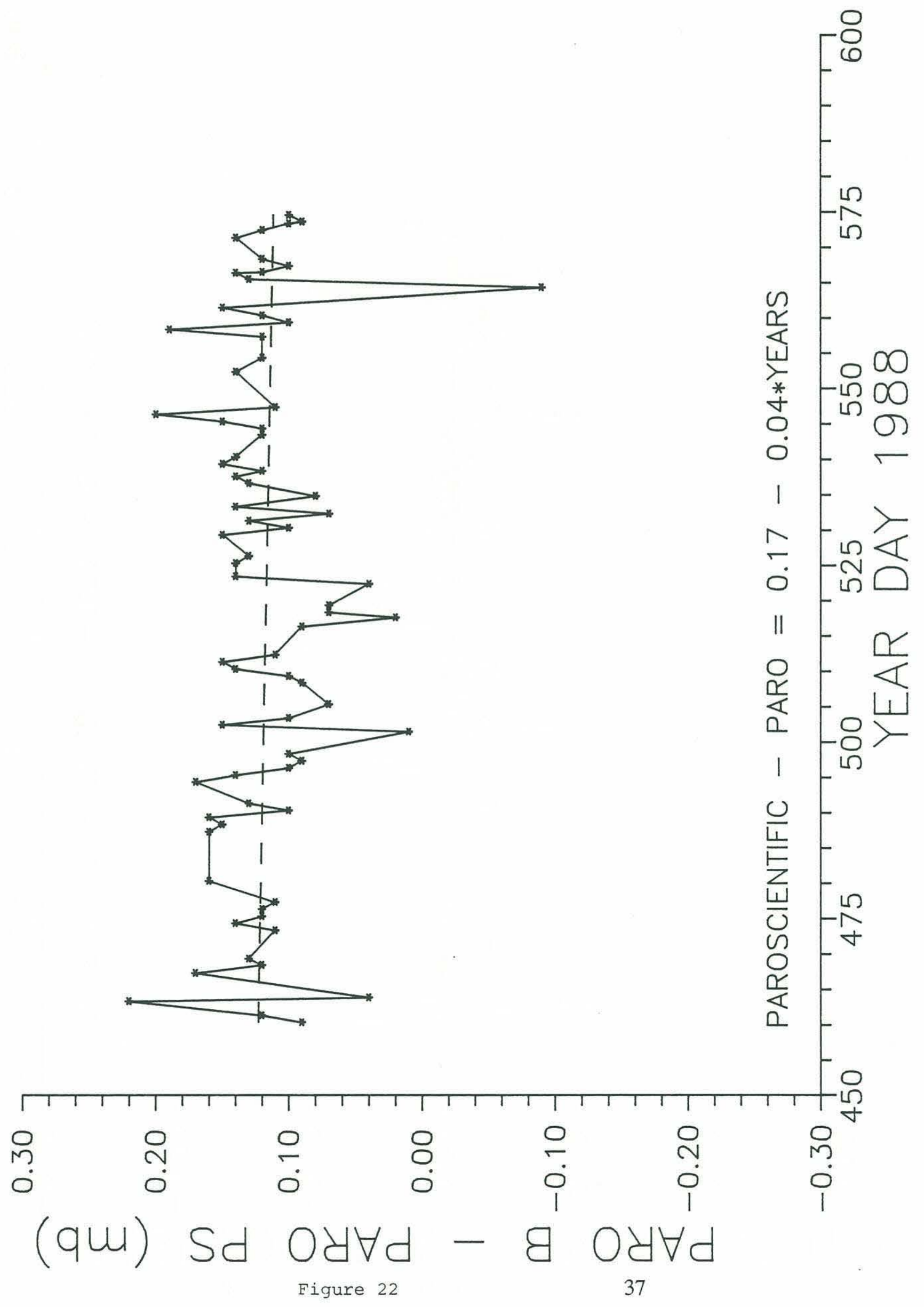




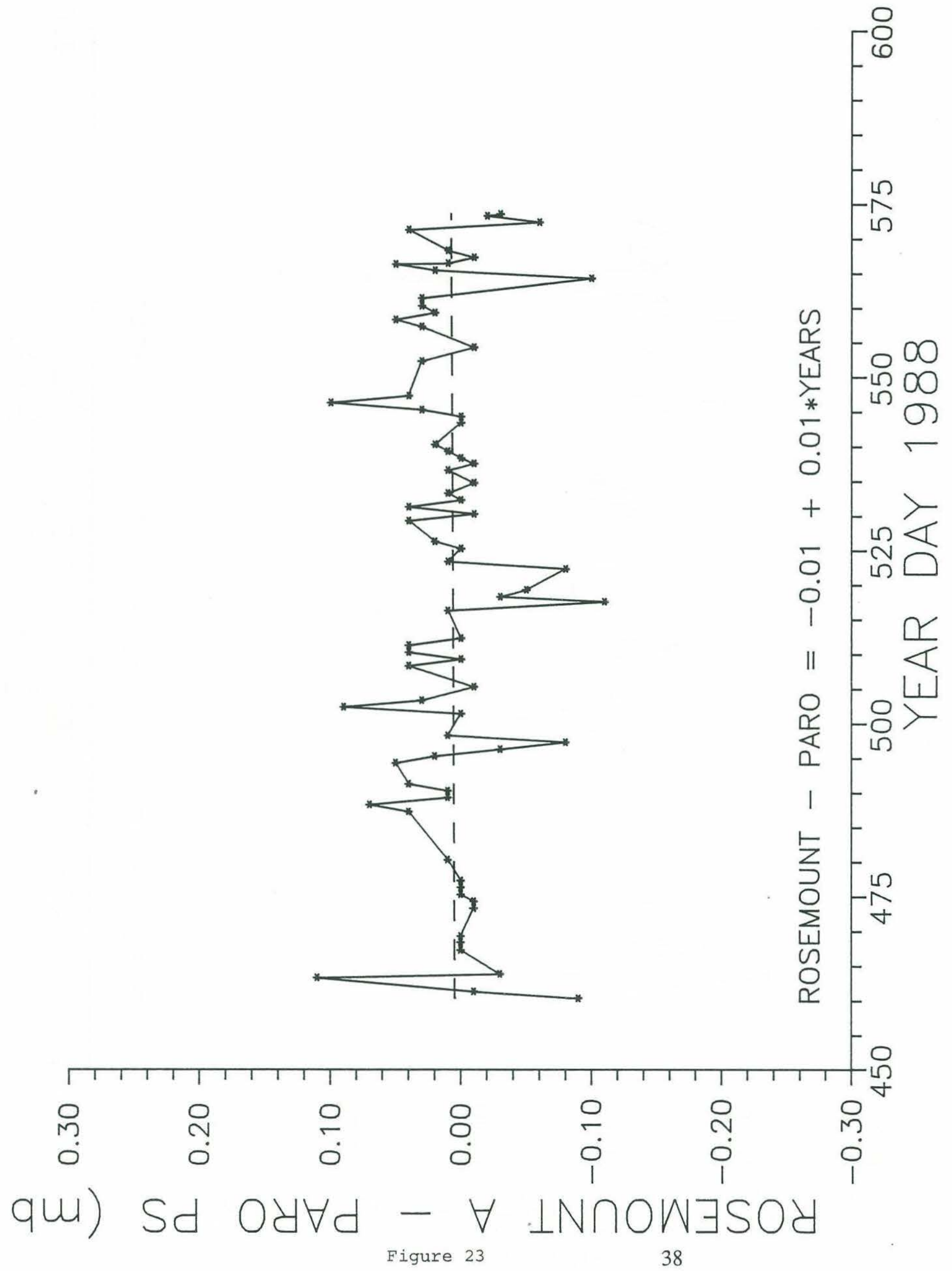




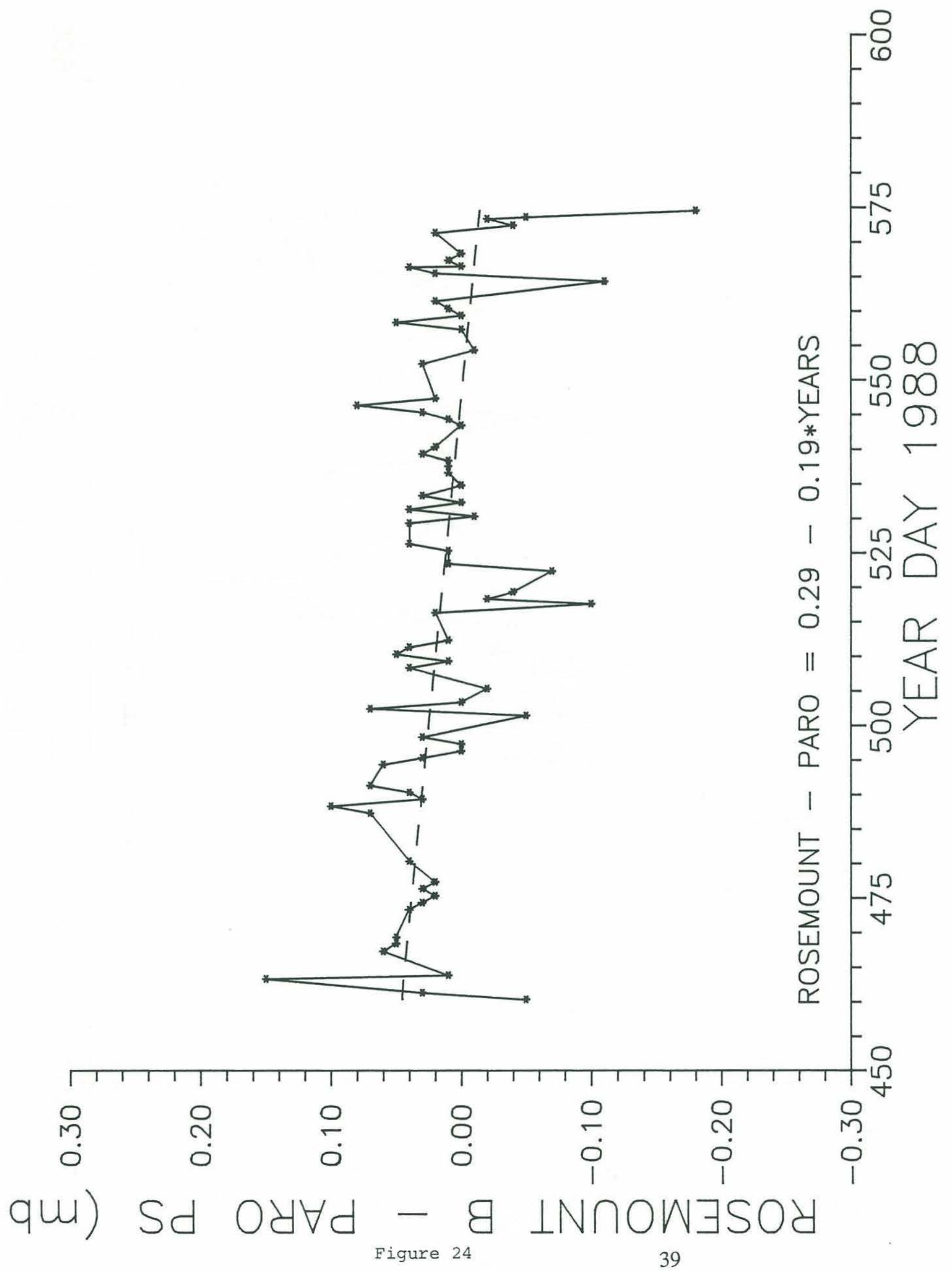




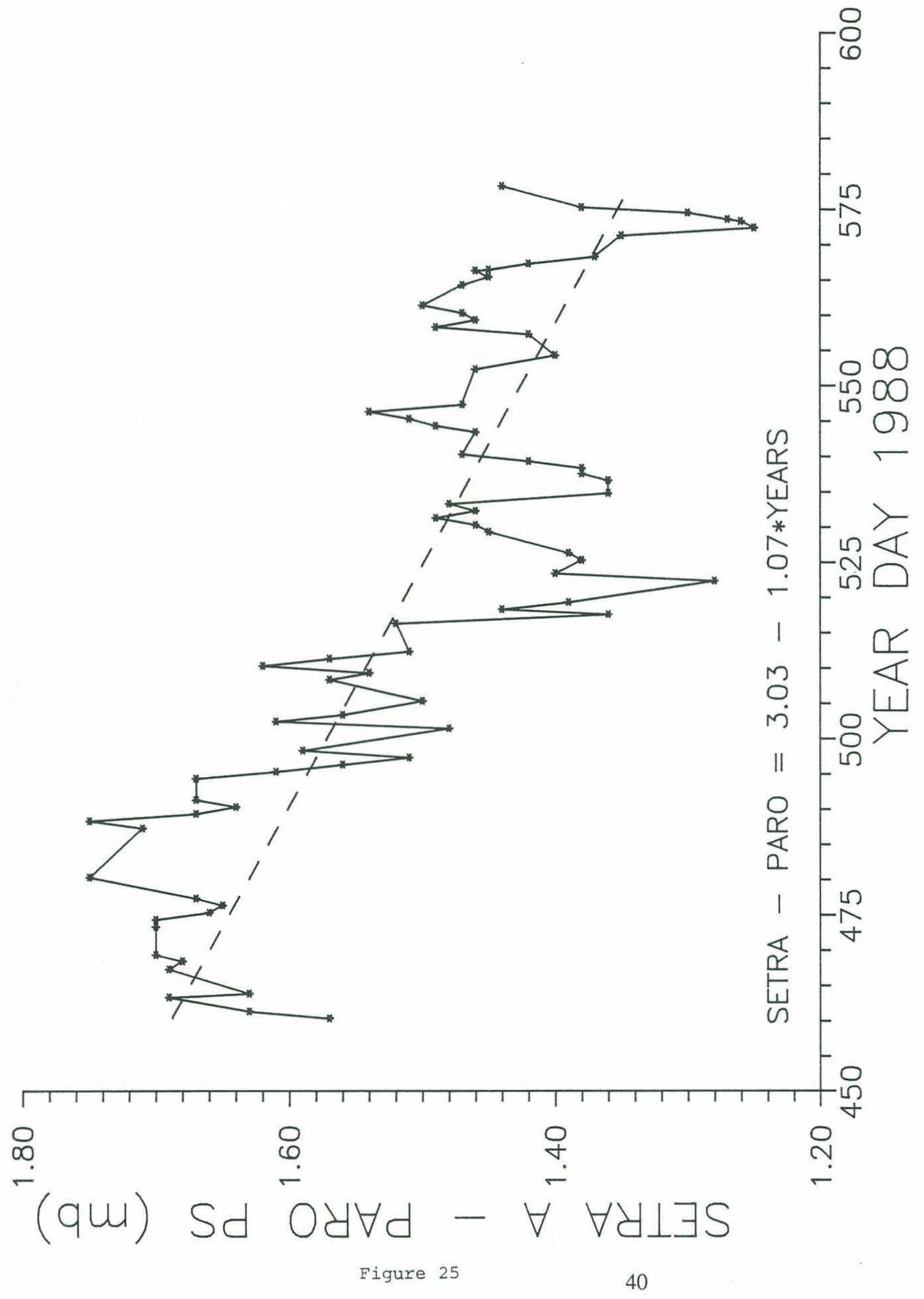




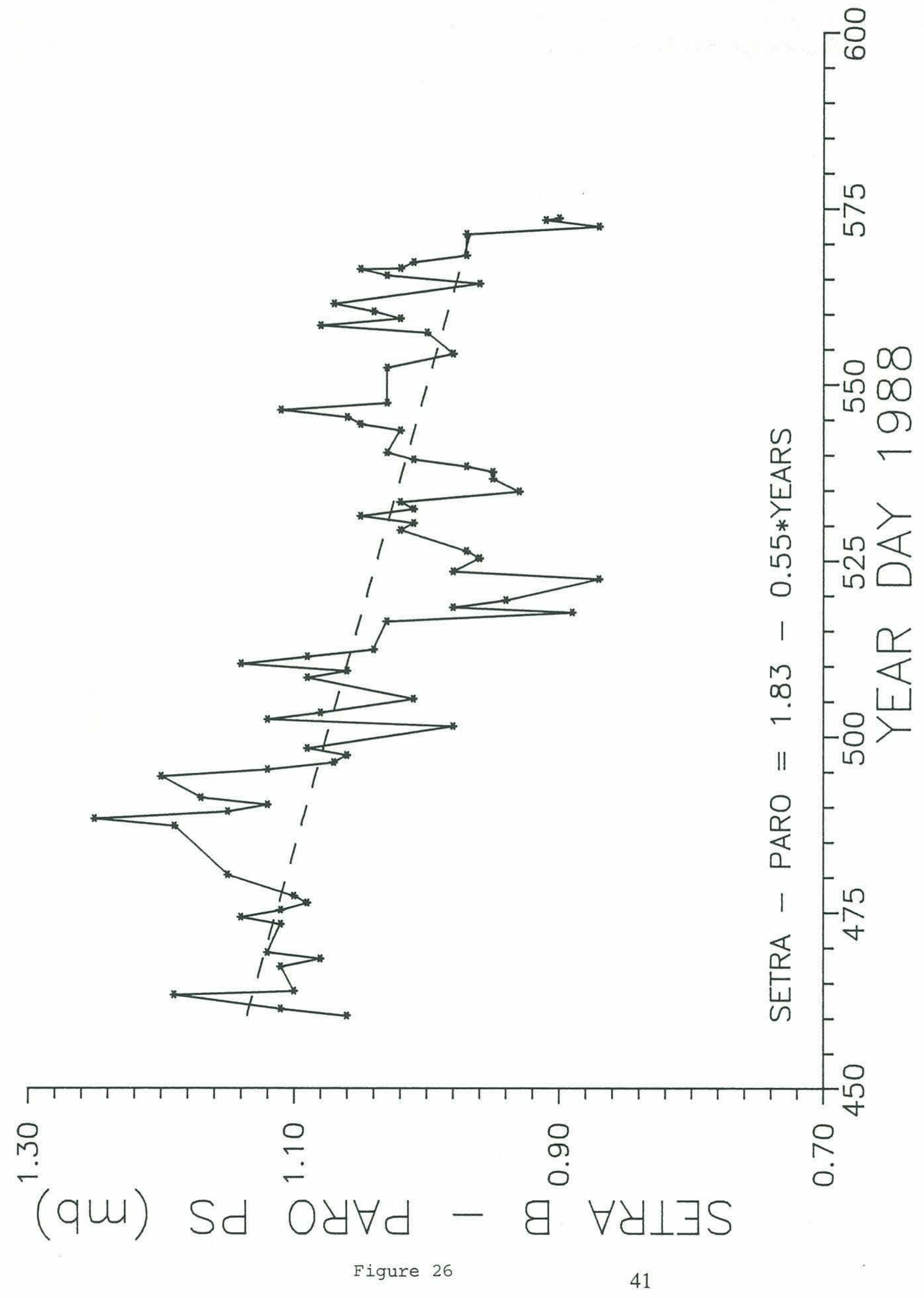




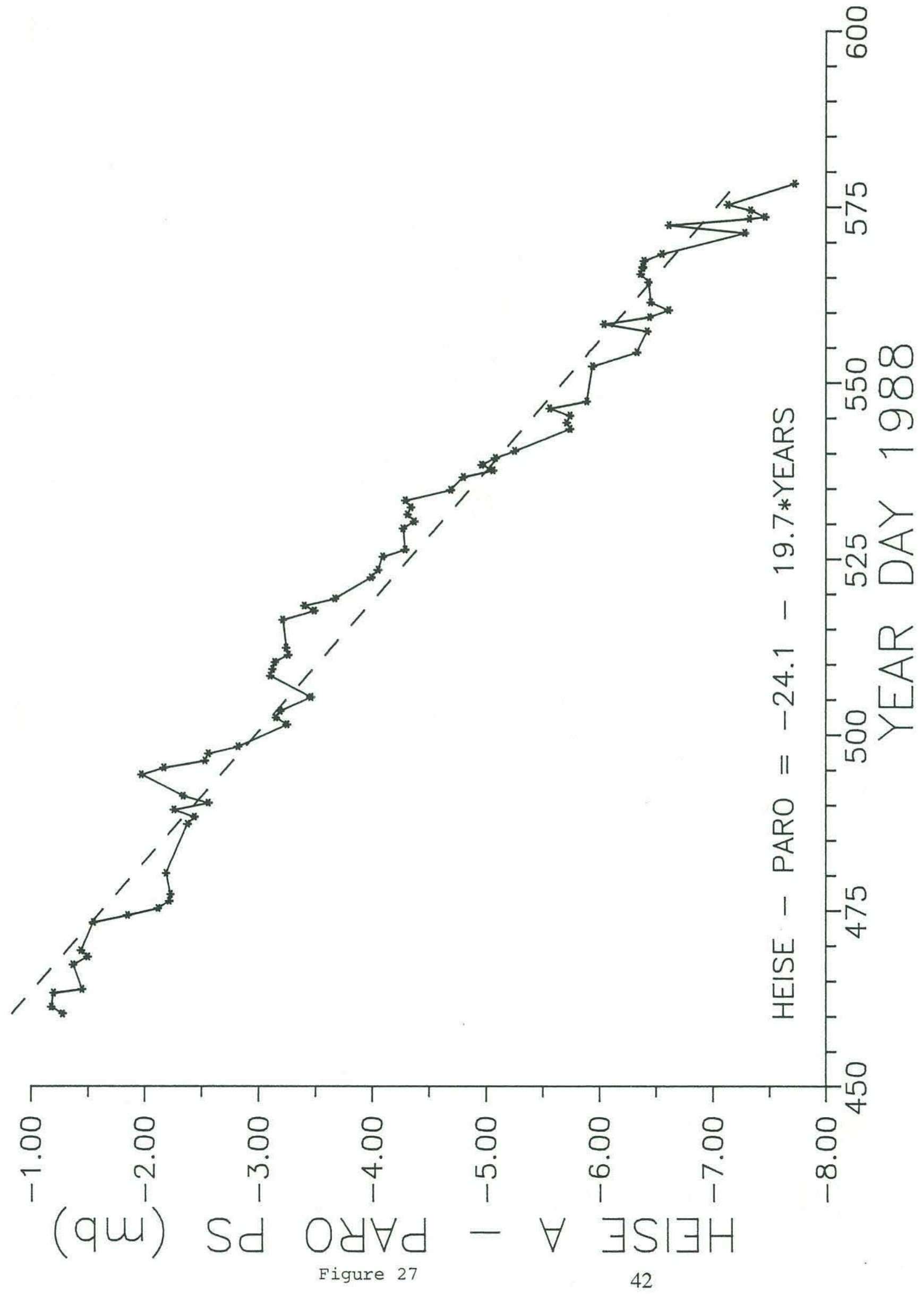




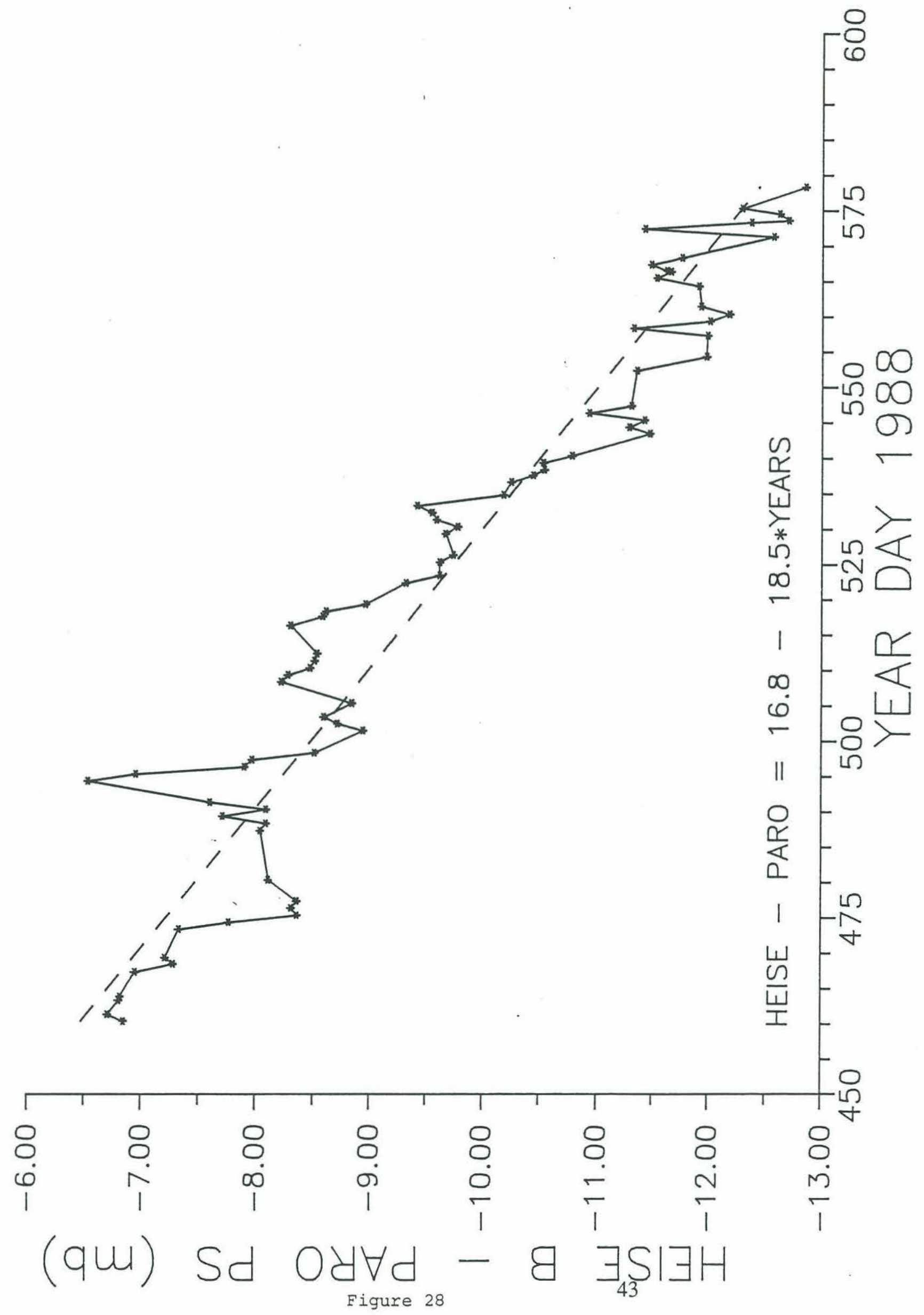




\section{DOCUMENT LIBRARY}

July 5, 1989

Distribution List for Technical Report Exchange

Attn: Stella Sanchez-Wade

Documents Section

Scripps Institution of Oceanography

Library, Mail Code C-075C

La Jolla, CA 92093

Hancock Library of Biology \& Oceanography

Alan Hancock Laboratory

University of Southern California

University Park

Los Angeles, CA 90089-0371

Gifts \& Exchanges

Library

Bedford Institute of Oceanography

P.O. Box 1006

Dartmouth, NS, B2Y 4A2, CANADA

Office of the International Ice Patrol

c/o Coast Guard R \& D Center

Avery Point

Groton, CT 06340

Library

Physical Oceanographic Laboratory

Nova University

8000 N. Ocean Drive

Dania, FL 33304

NOAA/EDIS Miami Library Center 4301 Rickenbacker Causeway

Miami, FL 33149

Library

Skidaway Institute of Oceanography

P.O. Box 13687

Savannah, GA 31416

Institute of Geophysics

University of Hawaii

Library Room 252

2525 Correa Road

Honolulu, HI 96822

Library

Chesapeake Bay Institute

4800 Atwell Road

Shady Side, MD 20876

MIT Libraries

Serial Journal Room 14E-210

Cambridge, MA 02139
Director, Ralph M. Parsons Laboratory Room 48-311

MIT

Cambridge, MA 02139

Marine Resources Information Center Building E38-320

MIT

Cambridge, MA 02139

Library

Lamont-Doherty Geological Observatory

Colombia University

Palisades, NY 10964

Library

Serials Department

Oregon State University

Corvallis, OR 97331

Pell Marine Science Library

University of Rhode Island

Narragansett Bay Campus

Narragansett, RI 02882

Working Collection

Texas A\&M University

Dept. of Oceanography

College Station, TX 77843

Library

Virginia Institute of Marine Science

Gloucester Point, VA 23062

Fisheries-Oceanography Library 151 Oceanography Teaching Bldg.

University of Washington

Seattle, WA 98195

Library

R.S.M.A.S.

University of Miami

4600 Rickenbacker Causeway

Miami, FL 33149

Maury Oceanographic Library

Naval Oceanographic Office

Bay St. Louis

NSTL, MS 39522-5001

Marine Sciences Collection

Mayaguez Campus Library

University of Puerto Rico

Mayagues, Puerto Rico 00708 


\begin{tabular}{|c|c|c|c|}
\hline $\begin{array}{l}\text { REPORT DOCUMENTATION } \\
\text { PAGE }\end{array}$ & $\begin{array}{l}\text { 1. REPORT NO. } \\
\text { WHOI-89-49 }\end{array}$ & 2. IMET TR 89-05 & 3. Recipient's Accession No. \\
\hline \multirow{2}{*}{\multicolumn{3}{|c|}{$\begin{array}{l}\text { 4. Title and Subtitle } \\
\text { Improved Meteorological Measurements from Buoys and Ships (IMET): } \\
\text { Preliminary Report on Barometric Pressure Sensors }\end{array}$}} & $\begin{array}{l}\text { 5. Report Date } \\
\text { December, } 1989\end{array}$ \\
\hline & & & 6. \\
\hline \multicolumn{3}{|c|}{$\begin{array}{l}\text { 7. Author(s) } \\
\text { Richard R. Payne, Gennaro H. Crescenti and Robert A. Weller }\end{array}$} & $\begin{array}{l}\text { 8. Performing Organization Rept. No. } \\
\text { WHOI-89-49 }\end{array}$ \\
\hline \multirow{2}{*}{\multicolumn{3}{|c|}{$\begin{array}{l}\text { 9. Performing Organization Name and Address } \\
\text { The Woods Hole Oceanographic Institution } \\
\text { Woods Hole, Massachusetts } 02543\end{array}$}} & 10. Project/Task/Work Unit No. \\
\hline & & & $\begin{array}{l}\text { 11. Contract(C) or Grant(G) No. } \\
\text { (C) } \\
\text { (G) OCE } 87-09614\end{array}$ \\
\hline \multirow{2}{*}{\multicolumn{3}{|c|}{$\begin{array}{l}\text { 12. Sponsoring Organization Name and Address } \\
\text { Funding was provided by the National Science Foundation }\end{array}$}} & $\begin{array}{l}\text { 13. Type of Report \& Period Covered } \\
\text { Technical Report }\end{array}$ \\
\hline & & & 14. \\
\hline
\end{tabular}

15. Supplementary Notes

This report should be cited as: Woods Hole Oceanog. Inst. Tech. Rept., WHOI-89-49, IMET TR-89-05

16. Abstract (Limit: 200 words)

Stability tests over periods ranging from 3 to 19 months have been carried out on Paroscientific models 215-AT and 760-15A, AIR DB-1A, Rosemount 1201F1B, Setra 270 and Heise 623 electronic barometers. The Paroscientific barometers had the highest accuracy, stability, and price, and the lowest power consumption. The Rosemount 1201F1B had excellent stability but high power consumption as well as price. The AIR DB-1A and Setra 270 have good stability and moderate power consumption and price. The tests are being expanded to include inexpensive sensors.

17. Document Analysis a. Descriptors

1. surface meteorology

2. barometric pressure

3. sensor evaluation

b. Identifiers/Open-Ended Terms

c. COSATI Field/Group

18. Availability Statement

Approved for publication; distribution unlimited.

\begin{tabular}{|l|l|}
\hline $\begin{array}{c}\text { 19. Security Class (This Report) } \\
\text { UNCLASSIFIED }\end{array}$ & $\begin{array}{c}\text { 21. No. of Pages } \\
43\end{array}$ \\
\hline 20. Security Class (This Page) & 22. Price \\
\hline
\end{tabular}

